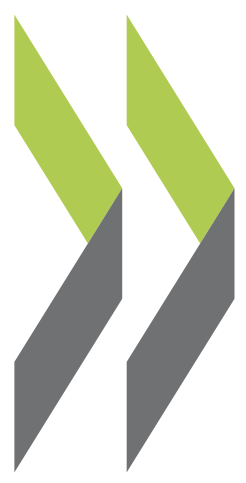

OECD Economics Department Working Papers No. 1134

Comparing the Robustness

of PAYG Pension Schemes

Falilou Fall

https://dx.doi.org/10.1787/5jz158w3ghmx-en 
Organisation de Coopération et de Développement Économiques

Organisation for Economic Co-operation and Development

03-Jul-2014

ECONOMICS DEPARTMENT

English - Or. English

COMPARING THE ROBUSTNESS OF PAYG PENSION SCHEMES

ECONOMICS DEPARTMENT WORKING PAPERS No. 1134

\section{By Falilou Fall}

OECD Working Papers should not be reported as representing the official views of the OECD or of its member countries. The opinions expressed and arguments employed are those of the author(s).

Authorised for publication by Jean-Luc Schneider, Deputy Director, Policy Studies Branch, Economics Department.

All Economics Department Working Papers are available through OECD's Internet website at http://www.oecd.org/eco/workingpapers

JT03360139

Complete document available on OLIS in its original format

This document and any map included herein are without prejudice to the status of or sovereignty over any territory, to the delimitation of international frontiers and boundaries and to the name of any territory, city or area. 
OECD Working Papers should not be reported as representing the official views of the OECD or of its member countries. The opinions expressed and arguments employed are those of the author(s).

Working Papers describe preliminary results or research in progress by the author(s) and are published to stimulate discussion on a broad range of issues on which the OECD works.

Comments on Working Papers are welcomed, and may be sent to the Economics Department, OECD, 2 rue André-Pascal, 75775 Paris Cedex 16, France, or by e-mail to eco.contact@oecd.org.

This document and any map included herein are without prejudice to the status of or sovereignty over any territory, to the delimitation of international frontiers and boundaries and to the name of any territory, city or area.

The statistical data for Israel are supplied by and under the responsibility of the relevant Israeli authorities. The use of such data by the OECD is without prejudice to the status of the Golan Heights, East Jerusalem and Israeli settlements in the West Bank under the terms of international law.

\section{() OECD (2014)}

You can copy, download or print OECD content for your own use, and you can include excerpts from OECD publications, databases and multimedia products in your own documents, presentations, blogs, websites and teaching materials, provided that suitable acknowledgment of OECD as source and copyright owner is given. All requests for commercial use and translation rights should be submitted to rights@oecd.org 


\section{ABSTRACT / RÉSUMÉ}

\section{Comparing the robustness of PAYG pension schemes}

This paper provides a framework for comparing a defined benefit (DB) and a defined contribution (DC) point schemes, which are both pay-as-you go (PAYG) financed. Two stylised PAYG pension schemes are modelled and simulated to compare their robustness to shocks. The same demographic developments (distribution of workers by age and revenue and distribution of survival rate by age) are applied to the two schemes. The impacts of different shocks (productivity, migration and longevity) on the two schemes are compared. Different policy reforms (increasing the contribution rate, diminishing the pension benefit, changing the up-rating and increasing the retirement age) to cope with the ageing shock are analysed and compared.

JEL classification codes: H55; H75; J32; C6

Keywords: Pension, pension systems, pension modelling, defined benefit, defined contribution, ageing, sustainability

\section{Une comparaison de la robustesse des systèmes de retraite en répartition}

Ce document fournit un cadre pour comparer des systèmes de retraite en répartition à prestations définies et à cotisations définies. Deux régimes de retraite par répartition stylisés sont modélisés et simulés pour comparer leur robustesse aux chocs. Les mêmes évolutions démographiques (distribution des travailleurs selon l'âge et les revenus et des taux de survie par âge) sont appliquées aux deux régimes. Les impacts des différents chocs (productivité, migration et longévité) sur les deux systèmes sont comparés. Et, les différentes réformes (augmentation du taux de cotisation, diminution des prestations de retraite, changement du mode d'actualisation des salaires passés et augmentation de l'âge de la retraite) pour faire face au choc du vieillissement sont analysées et comparées.

Classification JEL : H55 ; H75 ; J32 ; C6

Mots clés : Retraite, modélisation de la retraite, prestations définies, contributions définies, vieillissement, durabilité 


\section{TABLE OF CONTENTS}

COMPARING THE ROBUSTNESS OF PAYG PENSION SCHEMES ….............................................. 6

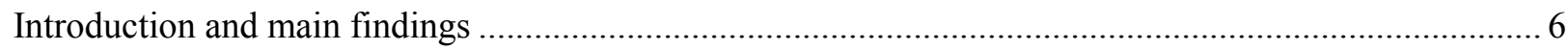

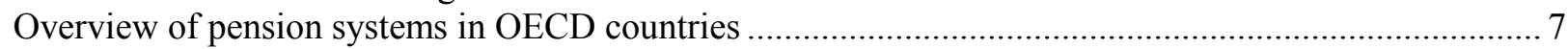

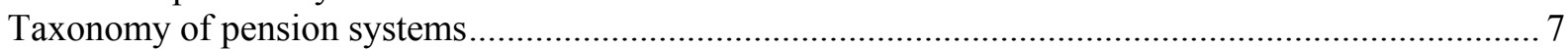

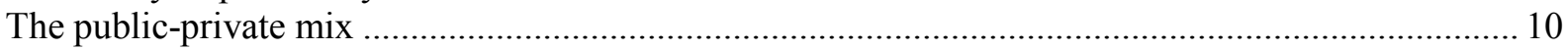

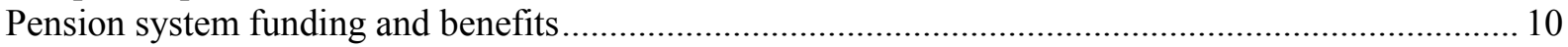

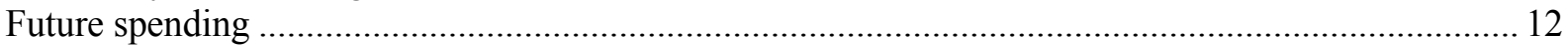

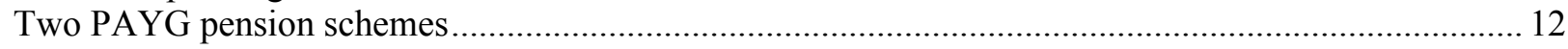

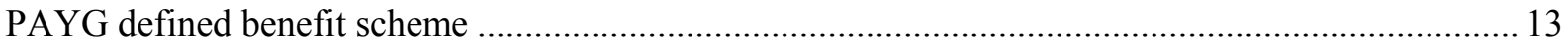

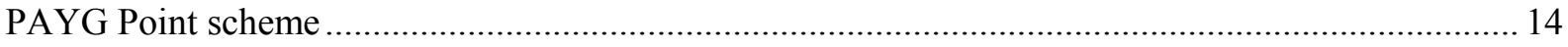

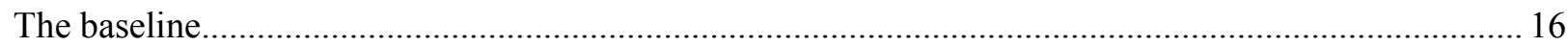

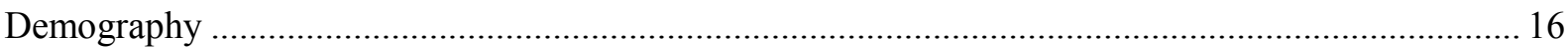

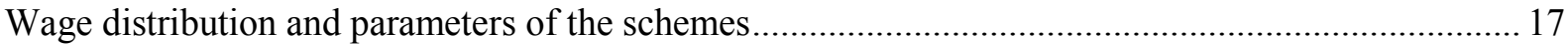

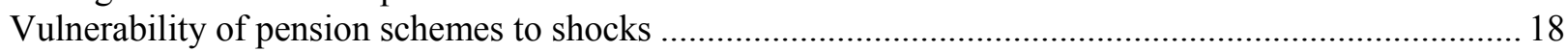

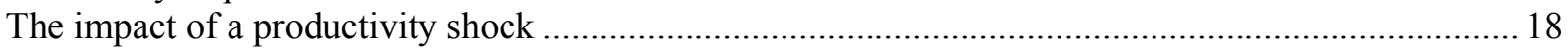

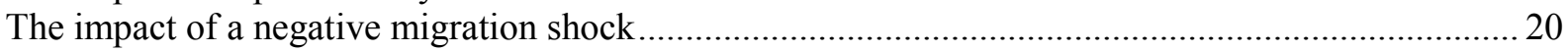

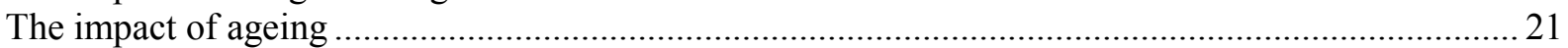

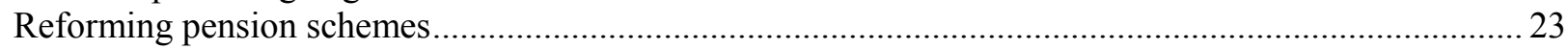

The impact of increasing the contribution rate in the two schemes.....................................................2 23

The impact of increasing the retirement age in the two schemes ........................................................24

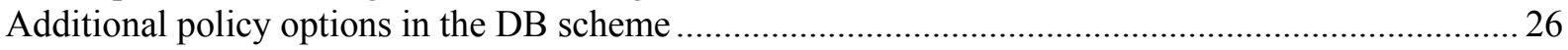

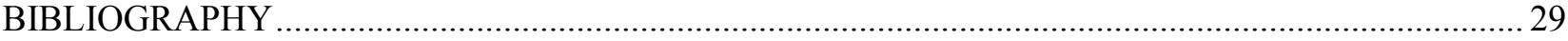

\section{Table}

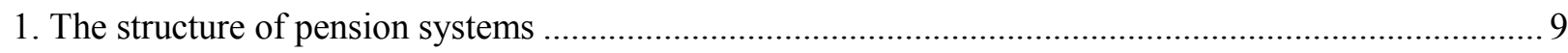

\section{Figures}

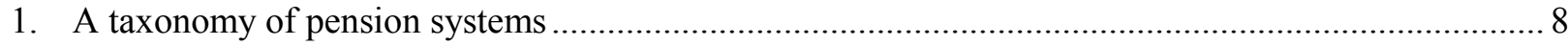

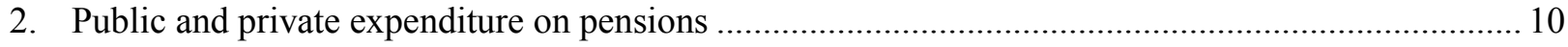

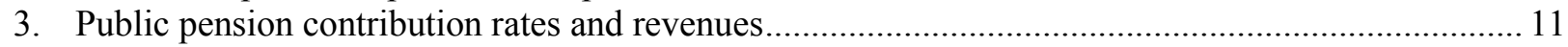

4. Net pension replacement rates from public and mandatory private schemes

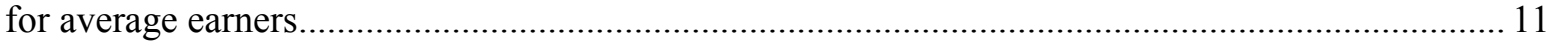

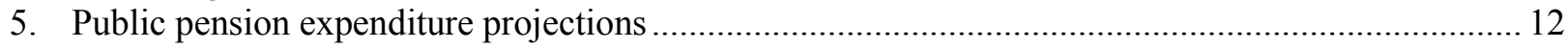

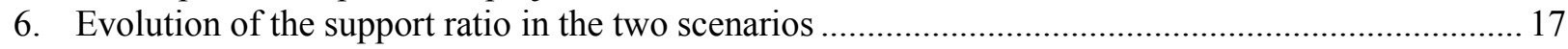

7. The effect of a productivity growth slowdown on a DB scheme …............................................ 19

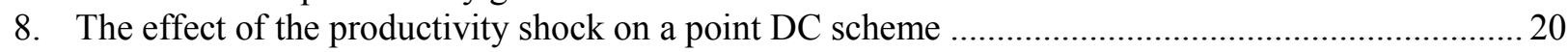

9. The impact of a negative migration shock on DB and DC schemes ............................................. 21

10. The impact of a negative migration shock on DB and DC schemes ...............................................2 22

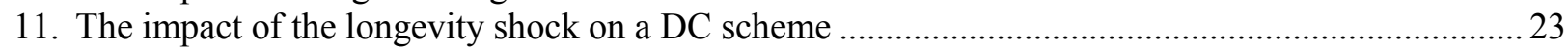


12. The impact of increasing the contribution rate on the DB scheme................................................24

13. The impact of increasing the retirement age from 60 to 65 in the DB scheme ...............................25

14. The impact of increasing the retirement age from 60 to 65 on the point scheme .............................26

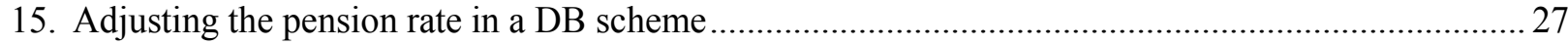

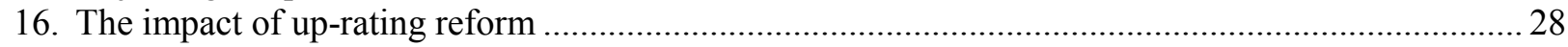

\section{Boxes}

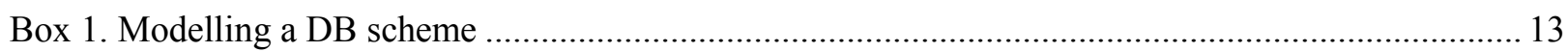

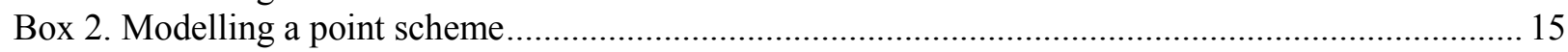




\title{
COMPARING THE ROBUSTNESS OF PAYG PENSION SCHEMES
}

\author{
By Falilou Fall ${ }^{1}$
}

\section{Introduction and main findings}

1. This paper provides a framework for modelling defined benefit (DB) and defined contribution (DC) point schemes, which are both pay-as-you go (PAYG) financed. Most sustainability issues pertain to unfunded schemes. Sustainability is less an issue for funded defined contribution schemes as pensions are financed by the contributions and their returns on accumulated assets. In particular, in funded defined contribution schemes, individuals bear the different risks (for instance, concerning investment or longevity).

2. Two stylised PAYG pension schemes are modelled and simulated to compare their robustness to shocks. A stylised version of each scheme is developed, based on the same demographic developments (distribution of workers by age and revenue and distribution of survival rate by age).

3. Notional defined contribution (NDC) schemes (as in Sweden and Italy) are not modelled, but their functioning is close to a point scheme with the difference that contributions are recorded in individual accounts.

4. The main findings are:

- Lower trend productivity growth decreases pension benefits paid out by a DB scheme in the long run, thus affecting adequacy. The balance of the DB scheme deteriorates because pension revenues decreases more than pension spending.

- A negative permanent migration shock has a temporary negative effect on the balance of the DB scheme. In the long run, the DB scheme reverts to balance. As the DC point scheme is balanced by definition, it is the average pension which is negatively affected by the migration shock. A negative migration shock is similar to a negative fertility rate shock.

- A rise in longevity (ageing shock) increases the number of pensioners and decreases the support ratio (the number of contributors per pensioner). The longevity shock reduces the support ratio from 2.3 to 1.5 in the long run. The effect of the ageing shock on the DB scheme is straightforward. As the number of pensioners increases, the balance of the DB scheme deteriorates. In the long run, the deficit of the DB scheme reaches $30 \%$ of baseline revenues. In

1. The author is a member of the Economics Department of the OECD. The author thanks Anna d'Addio, Pablo Antolin, Debbie Bloch, Hervé Boulhol, Peter Hoeller, Jon Pareliussen, Mauro Pisu, Monika Queisser and Jean-Luc Schneider for comments on earlier drafts and Celia Rutkoski for assistance in preparing the document. Special thanks go to Yann Balgobin, Mattias Mano and Martin Quinn for their excellent research assistance. The opinions expressed in this paper are the author's and do not necessarily correspond to those of the OECD or its member countries. All remaining errors are the responsibility of the author. 
the DC point scheme, it is the average replacement rate (the ratio of average pensions to the average wage) which decreases sharply. In the long run, the average replacement rate is $13 \%$ lower in the ageing scenario compared with the baseline scenario.

- To cope with the ageing shock, the contribution rate can be increased in the DB scheme. In the point DC scheme, the contribution rate cannot be the only parameter that adjusts to the ageing shock as pension rights increase with higher contributions. The service value has to decrease along with the increase in the contribution rate.

- In the DB scheme, the pension rate and the up-rating rate of past wages can be adjusted to cope with the ageing shock. They both diminish pension benefits and can raise adequacy issues.

- An increase of the retirement age improves the balance of the DB scheme and pension benefits in the DC point scheme. However, the success of the reform hinges on achieving higher employment rates for older workers.

- The simulations do not take into account side effects of reforms. For instance, the effect of the increase of the contribution rate to fund pension schemes on employment is not taken into account. Increasing the contribution rate could decrease employment and thus partially offset the improvement in the balance of the pension scheme.

5. Section 2 presents an overview of pension systems in OECD countries. In particular, the types of pension schemes and the outlook for future pension spending in the face of ageing are explored. In Section 3, the two PAYG pension schemes (DB and DC point scheme) are laid out and the rules for pension right accumulation and pension calculation are presented. Section 4 sets out the baseline, in particular demographic developments and the wage distribution. In Section 5, the impact of different shocks (productivity, migration and longevity) on the two schemes are compared and analysed. In Section 6, different policy reforms (increasing the contribution rate, diminishing the pension benefit and increasing the retirement age) to cope with the ageing shock are analysed and compared.

\section{Overview of pension systems in OECD countries}

\section{Taxonomy of pension systems}

6. Pension systems are diverse and complex. The classification and overview, based on OECD (2013), groups the different schemes with regard to their main objectives and status (mandatory or voluntary). The OECD classification is based on the role and objective of each part of the system as illustrated in Figure 1. The first tier comprises schemes designed to ensure a minimum standard of living for pensioners. The second tier comprises earnings-related pension schemes. The third tier includes voluntary, private pension savings schemes. Within the second and third tiers, public and private schemes are distinguished and also the different types of schemes. 
Figure 1. A taxonomy of pension systems

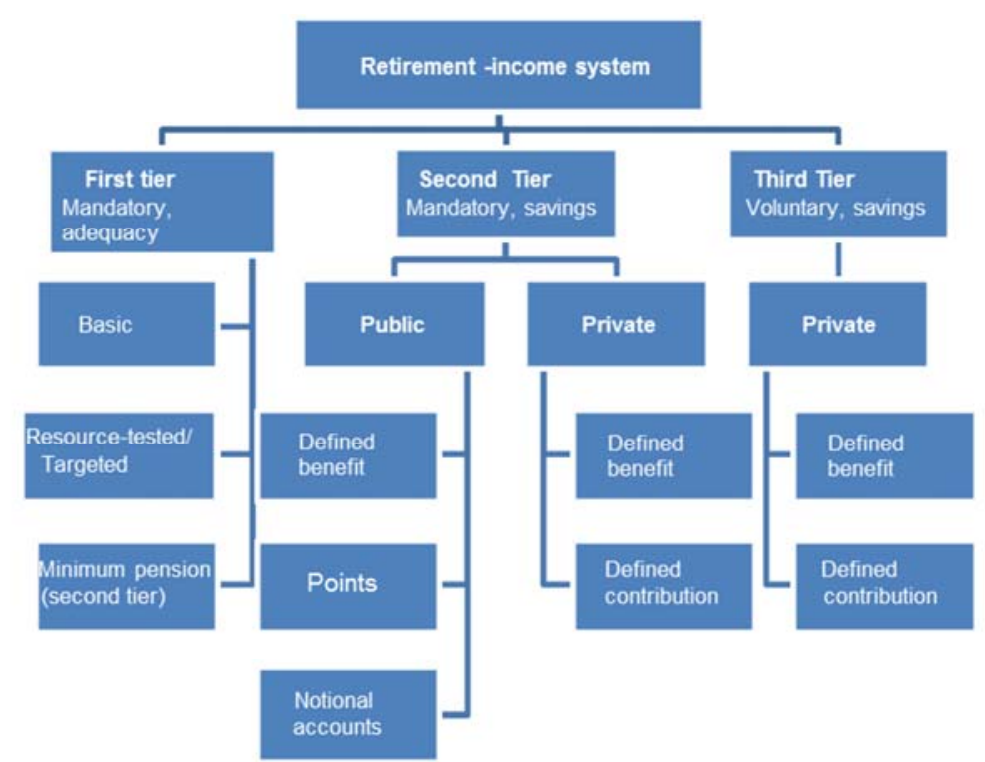

Source: OECD (2013), Pensions at a Glance 2013: OECD and G20 Indicators.

7. Based on this framework, national pension systems are presented in Table 1 in greater detail (OECD, 2013). The redistributive first tier provided by the public sector comprises three main types:

- Resource-tested or targeted schemes pay a benefit taking into account a pensioner's income from other sources or/and assets.

- Basic schemes pay either flat rate benefits (the same amount to every retiree) or their value depends only on years of work or on residency, not on past earnings.

- Minimum pensions depend on pension income: unlike resource-tested schemes, they are not affected by income from savings.

8. Only Ireland and New Zealand do not have mandatory, second-tier schemes. In the other 32 countries, there are four kinds of schemes (Table 1).

9. Defined-benefit (DB) plans are provided by the public sector in 18 OECD countries. Private (occupational) schemes are mandatory or quasi-mandatory in three OECD countries (Iceland, the Netherlands and Switzerland). Retirement income depends on the number of contribution years and individual earnings. Most of the DB schemes are pay-as-you-go (PAYG) as current contributions serve to pay current pensions.

10. Point schemes are in place in four OECD countries: French occupational pension plans and the Estonian, German and Slovak public schemes. Workers earn pension points based on their earnings each year. At retirement, the sum of pension points is multiplied by a pension-point value to convert them into a pension payment.

11. Defined-contribution (DC) plans are compulsory in 10 OECD countries. In these schemes, the accumulation of contributions and investment returns are recorded in individual accounts and converted 
into a pension-income stream at retirement. In Denmark and Sweden, there are quasi-mandatory, occupational DC schemes in addition to compulsory plans.

12. Notional defined contribution (NDC) schemes exist in four OECD countries (Italy, Norway, Poland and Sweden). The contributions are also recorded in an individual accounts and a yearly rate of return is applied to the balances. As they are PAYG systems, the accounts are "notional", as the balances exist only on the books of the managing institution. At retirement, the accumulated notional capital is converted into a stream of pension payments taking into account life expectancy.

Table 1. The structure of pension systems

\begin{tabular}{|c|c|c|c|c|c|}
\hline & \multicolumn{3}{|c|}{ Public } & \multirow[t]{2}{*}{ Public } & \multirow[t]{2}{*}{ Private } \\
\hline & Targeted & Basic & Minimum & & \\
\hline \multicolumn{6}{|l|}{ OECD members } \\
\hline Australia & $\checkmark$ & & & & DC \\
\hline Austria & & & & DB & \\
\hline Belgium & $\checkmark$ & & $\checkmark$ & DB & \\
\hline Canada & $\checkmark$ & $\checkmark$ & & DB & \\
\hline Chile & $\checkmark$ & & $\checkmark$ & & DC \\
\hline Czech Republic & & $\checkmark$ & $\checkmark$ & DB & \\
\hline Denmark & $\checkmark$ & $\checkmark$ & & & DC \\
\hline Estonia & & $\checkmark$ & & Points & DC \\
\hline Finland & & & $\checkmark$ & DB & \\
\hline France & & & $\checkmark$ & DB+points & \\
\hline Germany & $\checkmark$ & & & Points & \\
\hline Greece & & & $\checkmark$ & DB & \\
\hline Hungary & & & & DB & \\
\hline Iceland & $\checkmark$ & $\checkmark$ & & & DB \\
\hline Ireland & & $\checkmark$ & & & \\
\hline Israel & & $\checkmark$ & & & DC \\
\hline Italy & $\checkmark$ & & & NDC & \\
\hline Japan & & $\checkmark$ & & DB & \\
\hline Korea & $\checkmark$ & $\checkmark$ & & DB & \\
\hline Luxembourg & $\checkmark$ & $\checkmark$ & $\checkmark$ & DB & \\
\hline Mexico & & & $\checkmark$ & & DC \\
\hline Netherlands & & $\checkmark$ & & & DB \\
\hline New Zealand & & $\checkmark$ & & & \\
\hline Norway & & & $\checkmark$ & NDC & DC \\
\hline Poland & & & $\checkmark$ & NDC & DC \\
\hline Portugal & & & $\checkmark$ & DB & \\
\hline Slovak Republic & & & $\checkmark$ & Points & $D C$ \\
\hline Slovenia & & & $\checkmark$ & DB & \\
\hline Spain & & & $\checkmark$ & $\mathrm{DB}$ & \\
\hline Sweden & & & $\checkmark$ & NDC & DC \\
\hline Switzerland & $\checkmark$ & & $\checkmark$ & DB & DB \\
\hline Turkey & & & $\checkmark$ & DB & \\
\hline United Kingdom & $\checkmark$ & $\checkmark$ & $\checkmark$ & DB & \\
\hline United States & & & & DB & \\
\hline \multicolumn{6}{|l|}{ BRIICS } \\
\hline Brazil & & & & DB & \\
\hline China & & $\checkmark$ & & NDC/DC & \\
\hline India & & & & $\mathrm{DB}+\mathrm{DC}$ & \\
\hline Indonesia & & & & DC & \\
\hline Russian Federation & & $\checkmark$ & & NDC & DC \\
\hline South Africa & $\checkmark$ & & & & \\
\hline
\end{tabular}

Note: DB = Defined benefit; DC = Defined contribution; NDC = Notional accounts. In Iceland and Switzerland, the government sets contribution rates, minimum rates of return and the annuity rate at which the accumulation is converted into a pension for mandatory occupational plans. These schemes are therefore implicitly defined benefit.

Source: OECD (2013), Pensions at a Glance 2013: OECD and G20 Indicators. 


\section{The public-private mix}

13. The public-private mix of pension schemes depends on whether enrolment in private and occupational schemes is mandatory. It also depends on the coverage and generosity of the public pension scheme (Figure 2). High public pension replacement rates are correlated with low enrolment in private plans.

14. In 14 OECD countries, private pension enrolment is mandatory or near-universal coverage is achieved through collective agreements ("quasi-mandatory"). Switzerland and the Netherlands have the highest private pension provision as occupational plans are compulsory, followed by Australia, Canada and the United States. In these countries, it is the broad coverage of voluntary occupational plans that increases private pension's scope.

Figure 2. Public and private expenditure on pensions

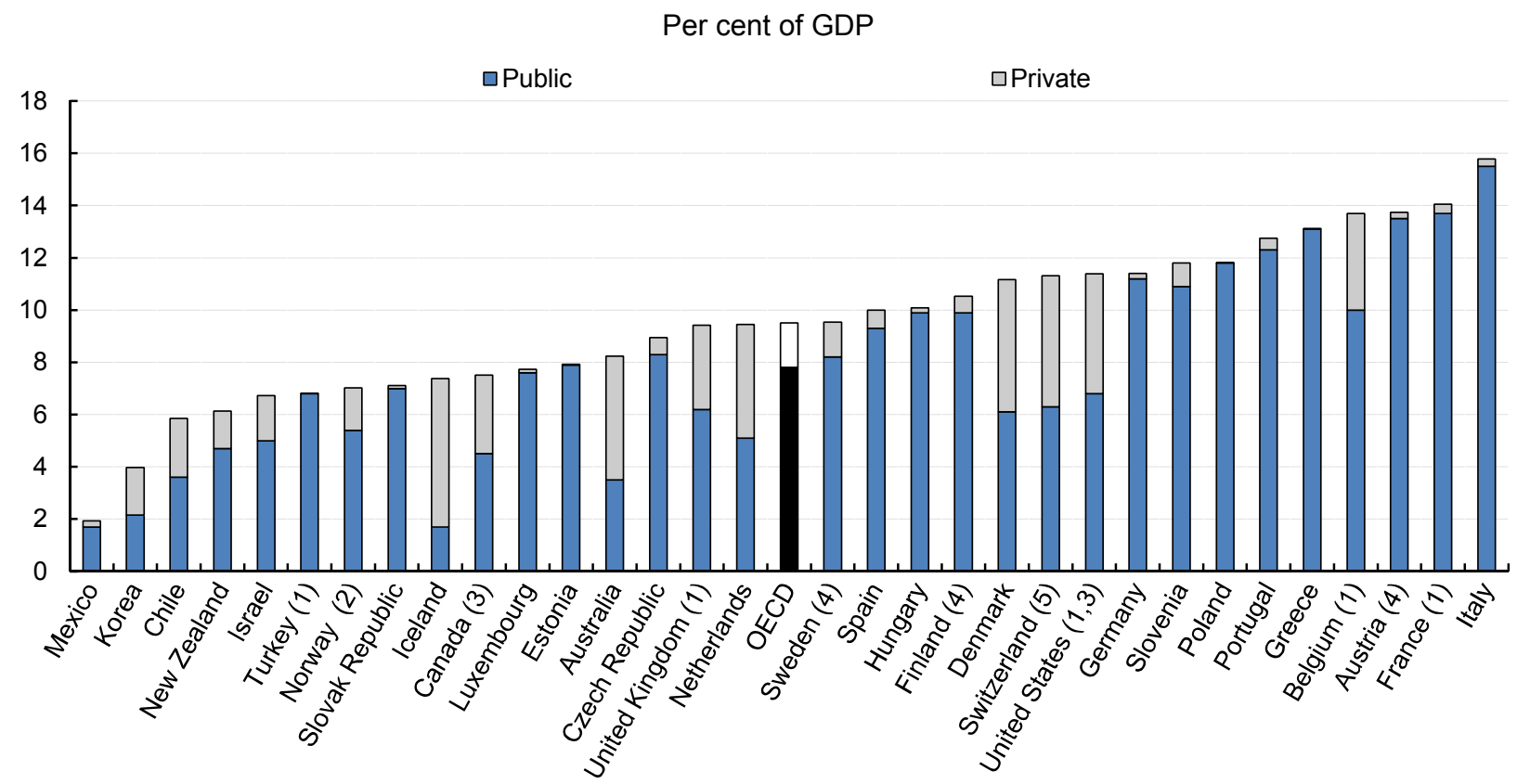

Note: All types of private plans are covered. Public and private pension spending refers respectively to 2009 and 2012 , unless otherwise specified.

1. Private pension data refer to 2011.

2. Private pension data refer to 2008.

3. Private pension data refer to pension funds only.

4. Private pension data refer to 2010

5. Public pension data refer to 2008.

Source: OECD Global Pension Statistics: OECD (2013), Pension Markets in Focus 2013.

\section{Pension system funding and benefits}

15. In 2012, the public pension contribution rate was $19.6 \%$ of gross earnings on average in the OECD. For some countries, contribution rates are higher than $30 \%$ of gross earnings (Italy and Hungary), while in Israel, Korea, Switzerland and Canada contribution rates are lower than 10\% (Figure 3).

16. Public pension (employee plus employer) contribution rates have remained broadly stable since the mid-1990s (OECD, 2013). The only significant increase in contribution rates was in the Czech Republic. This suggests that for many countries there was little room to increase contribution rates to 
finance increases in pension spending, because of concerns over the effect of higher labour taxes on employment.

Figure 3. Public pension contribution rates and revenues

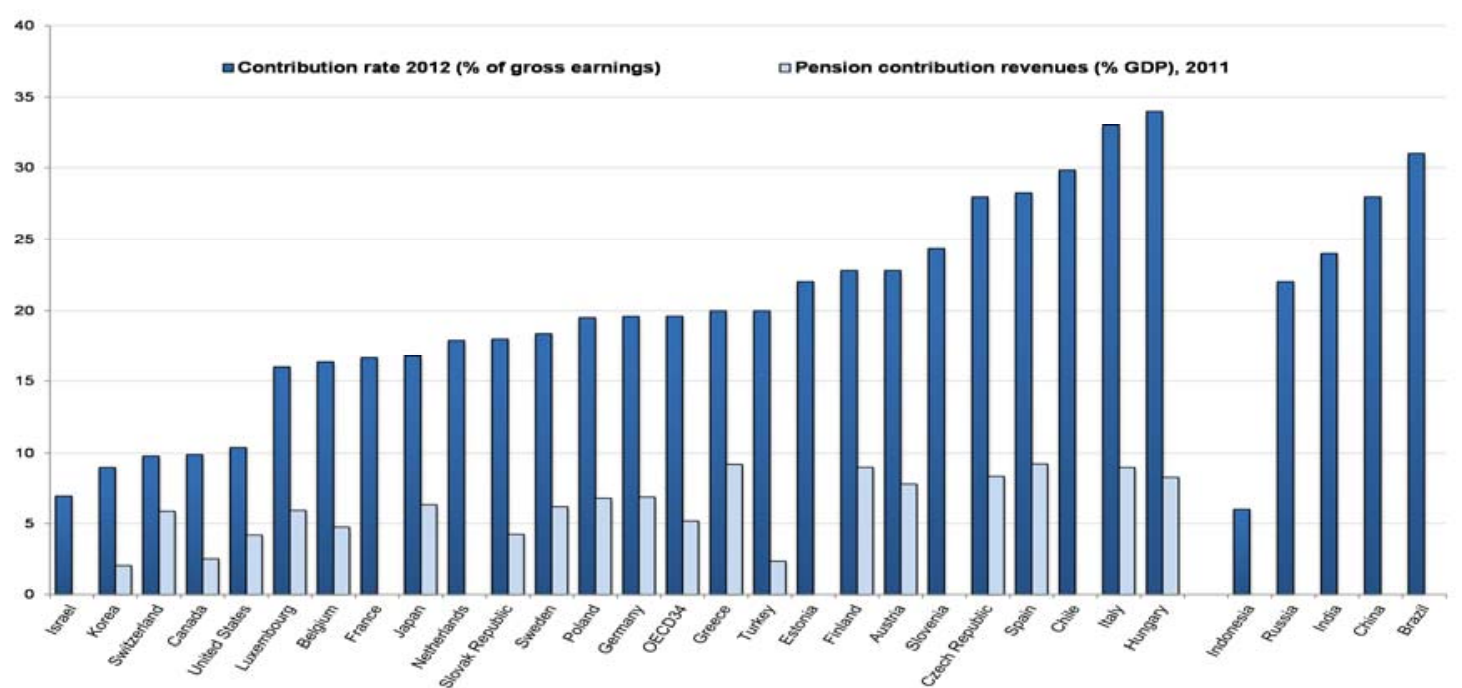

Note: Contribution rates are the sum of employee and employer contribution rates. OECD missing countries either do not have public contribution rates or no separable contribution rate for pension. The OECD average figure for contribution rates excludes the countries for which there are no pension contributions or they are part of contributions to wider social security programmes. In some cases, pension contribution revenues have been calculated assuming that the revenues are split between different social security programmes in the same proportion as the contribution rates. The total contribution revenues include payments from people who are not employees (principally the self-employed).

Source: OECD (2013), Pensions at a Glance 2013: OECD and G20 Indicators.

17. Public PAYG pension benefits represent the main income from mandatory pension schemes in most OECD countries. Exceptions are Mexico, Chile, Australia, Iceland, Israel and the Netherlands (Figure 4).

Figure 4. Net pension replacement rates from public and mandatory private schemes for average earners

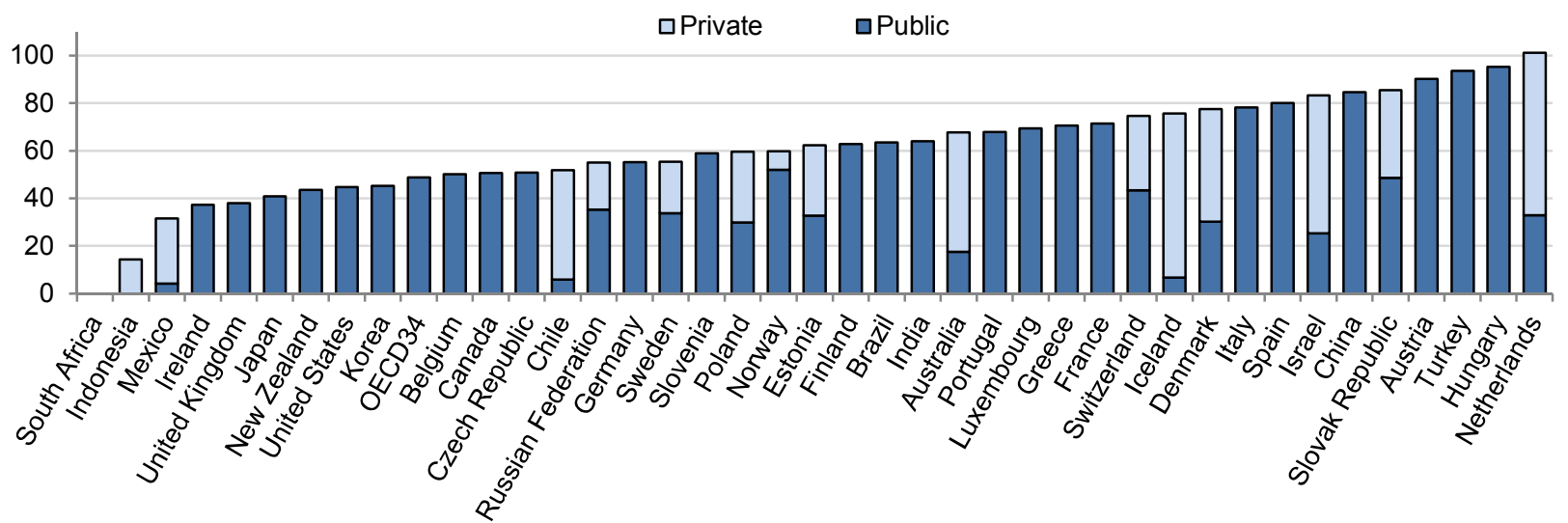

Note: The figure shows net pension replacement rates (i.e. the ratios of pension benefits to earnings after taxes and social security contributions) for full-career workers entering the labour market in 2012 at average earnings. The pension replacement rates are therefore forward-looking and apply to the future entitlements assuming that current pension rules will apply throughout their career until they reach the standard pension age.

Source: OECD pension models; OECD (2013), Pensions at a Glance 2013: OECD and G20 Indicators. 


\section{Future spending}

18. Public pension spending as a per cent of GDP is already high in many OECD countries and is expected to increase in the next decades due to ageing. In the European Union, a coordinated exercise among member countries provides pension projections taking into account demographic trends. OECD (2013) has, in addition, gathered national pension projections, though these are not done on a consistent basis. In almost all OECD countries (except Denmark, Estonia and Poland), pension spending (in per cent of GDP) is expected to increase (Figure 5).

Figure 5. Public pension expenditure projections

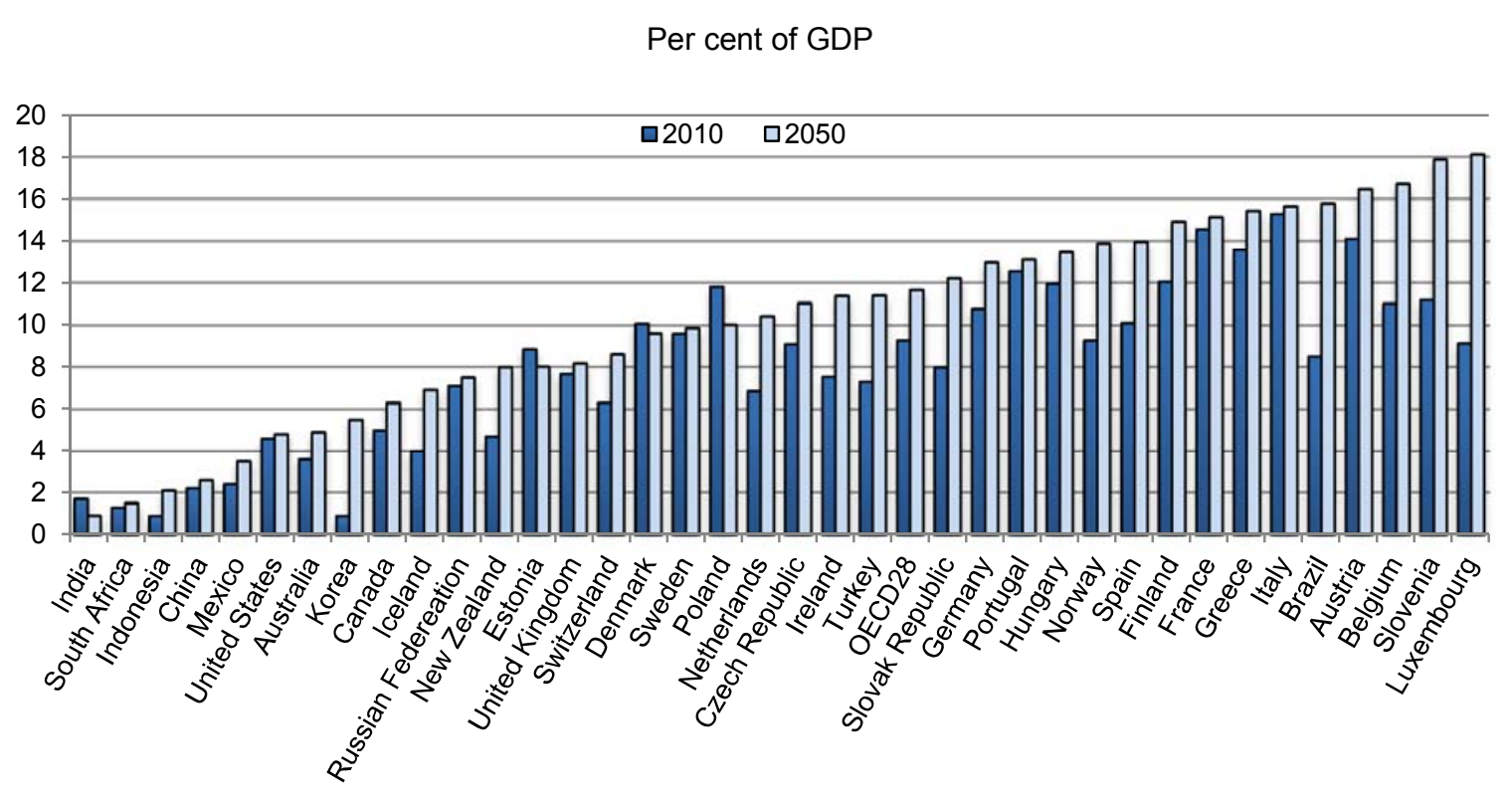

Note: The OECD28 aggregate shows only countries for which complete data between 2010 and 2050 are available. Pension schemes for civil servants and other public-sector workers are generally included in the calculations for EU member states. Expenditure on these schemes are not included for Canada, Japan, South Africa and the United States. Projections are not available, in some cases, for separate resource-tested programmes for retirees. This is the case for the United States and some EU member states. Similarly, data for Korea cover the earnings-related scheme but not the basic (resource-tested) pension.

Source: OECD (2013), Pensions at a Glance 2013: OECD and G20 Indicators.

19. These projections illustrate that pension schemes, in particular PAYG schemes, are highly vulnerable to demographic ageing. However, the different types of PAYG pension schemes are differently exposed to demographic shocks. Moreover, the different policy measures to cope with demographic shocks have different financial sustainability and adequacy effects on the different types of PAYG pension schemes. The following simulation exercises show the trade-off between sustainability and adequacy in two PAYG pension schemes.

\section{Two PAYG pension schemes}

20. The two main public PAYG pension schemes (DB and DC point scheme) are modelled and simulated to compare their robustness to shocks. A stylised version of each scheme is developed, but the same demography (distribution of workers by age and revenue and distribution of survival rate per age) is applied. 
21. Notional defined contribution (NDC) schemes (as in Sweden and Italy) are not modelled, but their functioning is close to a defined contribution point scheme with the difference that contributions are recorded in individual accounts. In theory, the internal rate of return on accumulated capital that guarantees the actuarial balance of the scheme has the same function as the implicit rate of return of the DC point scheme (Holzmann and Palmer, 2006). In both cases, the determination of the rate of return takes into account the evolution of life expectancy. However, in both cases, the ex-ante rate of return has to be revised with demographic and economic changes to guarantee the actuarial balance of the scheme. This violates the well-known result of Samuelson (1958) stating that, in steady state, defined by a fixed workforce, age and wage distribution and fixed mortality rates, the rate of return that guarantees financial equilibrium is the (instantaneous) rate of growth of the contribution base. Indeed, as demonstrated by Valdès-Prieto (2000) and Settergren and Mikula (2006), the Samuelson rate of return cannot alone maintain financial equilibrium when the wage distribution, mortality and the number of contributors change. Moreover, as far as the two schemes are financed under the PAYG principle, the matching between revenues and pension payments is not guaranteed and a balancing mechanism is needed.

\section{PAYG defined benefit scheme}

22. In the PAYG DB scheme, a contribution rate (employer plus employee) is applied to an individuals' wage to determine the contribution each year. At retirement, the pension is calculated by applying a pension rate to the reference salary, which is the average career salary. The reference salary depends on the revaluation index used to up-rate past salaries at the retirement year. The inflation rate is used as the indexation rate of pensions (Box 1).

23. At the scheme level, each year's contributions are used to pay current pensions. If pension spending exceeds total contributions the scheme is in deficit. The annual balance depends therefore, on the financing side, on the size of the payroll, the contribution rate and, on the spending side, on the number of retirees and on the average pension. The actuarial balance of the scheme is the sum of the discounted annual balance of the scheme over the projection period (up to 150 periods).

\section{Box 1. Modelling a DB scheme}

In the PAYG DB scheme, a contribution rate $(\tau)$ is applied to an individuals' wage to determine the contribution each year: ${ }^{1}$

$$
C_{i t}=\tau * W_{i t}
$$

At retirement, pensions are calculated by applying a pension rate to the reference salary. The reference salary can be the average career salary (life time earnings) or the average earnings over shorter periods. For instance, in Austria and France, it is respectively the best 24 and 25 years that are taken into account for calculating average earnings. In the simulation, the reference salary is averaged over the entire career. The reference salary depends on the revaluation index (inflation, wage growth or a mix) used to uprate past salaries at the retirement year. In this simulation exercise, the wage growth rate $\left(\omega_{t}\right)$ is used as revaluation rate to determine the reference wage $(R W)$ at retirement:

$$
R W_{t}=\frac{W_{t}+\sum_{i=1}^{T a} W_{t-i} \Pi_{i=1}^{T a}\left(1+\omega_{t-i}\right)}{T_{a}}
$$

In a PAYG pension scheme, the financing each year depends on the contribution rate and the payroll. ${ }^{2}$ The size of the payroll depends on the wage level, the size of the age-cohort of workers and employment. Total contributions perceived each year, with $\mathrm{NS}_{\mathrm{t}}$ the number of salaried workers in year $\mathrm{t}$, are:

$$
C(t)=\tau * \sum_{i=1}^{N S_{t}} W_{i t}
$$

The pension $(\mathrm{Pa})$ at retirement year $\mathrm{t}$ and age $(\mathrm{a}=60)$ of an individual can be written as a function of the scheme's pension rate $(\phi=0.5)$, the contribution periods validated by the individual at age a $\left(T_{a}\right)$, the required contribution period for a full pension $\left(T^{*}=40\right.$ years $)$ and the reference wage $(R W)$ : 


$$
P_{a t}=\emptyset * \frac{T_{a}}{T^{*}} * R W_{t}
$$

The individual pension rate $\theta_{\mathrm{i}}=\phi^{*}\left(\mathrm{Ta} / \mathrm{T}^{*}\right)$ depends on the validated contribution periods. In many countries, when the validated contribution period is lower (or higher) than the contribution period required for a full pension, the full pension rate is reduced (or increased) by a penalty (or bonus). The full pension rate $(\phi)$ can also be increased or decreased with respect to deferred or early retirement.

The effective individual annuity rate or annual accrual rate depends on the total contributed periods validated for an individual $A i=\theta_{i} / T a$. When the validated contribution periods are equal to the required contribution periods for a full pension rate then the annuity rate is equal to the ratio of the full pension rate to the required contribution period $\mathrm{Aa}=\phi / \mathrm{T}^{*}$. As $\mathrm{T}^{*}$ is equal to 40 years of contributions, the maximum annual accrual rate is $1.25 \%\left(\phi / T^{*}\right)$. It is, for instance, $1.33 \%$ for men in Belgium and $1.5 \%$ in the Czech Republic.

At the scheme level, the spending, each year, depends on the pension level and the size of the different cohorts of retirees. Denoting NRt the number of retirees at year $t$, the total amount of pensions paid to the cohort retiring at year $t$ is:

$$
R_{t}=\sum_{i=1}^{N R_{t}} \theta_{i} * R W_{i t}
$$

Therefore pension spending at year $t$ can be written as the sum of pensions of the new retiring cohort plus pension spending of the previous year revalued by the inflation rate $\left(\pi_{t}\right)$ minus the pensions of the deceased (factor $\sigma)^{3}$

$$
P S_{t}=R_{t}+P S_{t-1}\left(1+\pi_{t}\right)(1-\sigma)
$$

At the scheme level, each year's contributions perceived are used to pay current pensions. If pension spending exceeds total contributions the scheme is in deficit. The actuarial balance of the scheme is the sum of the expected annual balances of the scheme over the projection period. The annual balance depends therefore, on the financing side, on the size of the payroll, the contribution rate and, on the spending side, on the number of retirees and on the average pension.

At year $t$, the short-term balance of the PAYG DB scheme can be written as:

$$
C_{t}-P S_{t}=X_{t}
$$

When $X_{t}$ is equal to zero then the pension scheme is in equilibrium in year t. However, $X_{t}$ could be different from zero for various reasons, for instance, changes in the support ratio due to ageing.

The long-term actuarial balance of the PAYG defined benefit scheme can be written as the projected sequence of short-term balances over the projection period. ${ }^{4}$ The actuarial balance of the pension scheme over a time-span $\mathrm{T}$ at year $\mathrm{t}$ is:

$$
\sum_{j=0}^{T} \frac{C_{t+j}}{(1+\beta)^{j}}-\sum_{j=0}^{T} \frac{P S_{t+j}}{(1+\beta)^{j}}=\sum_{j=0}^{T} \frac{X_{t+j}}{(1+\beta)^{j}}
$$

where $\beta$ is the discount rate of future flows of total contributions, pension spending and net balances. In the simulation $\beta$ is set equal to $1.5 \%$.

1. The presentation of the different models is simplified by not considering the ceilings on wages that may exist in different schemes and also the existence of minimum pensions.

2. For some countries, basic pensions are financed by the central government budget.

3. In the simulation, a mortality table giving mortality rate by age and year is used to determine the deceased each year. For illustrative purposes, the French mortality table is used.

4. There are different concepts of actuarial balance of pension schemes depending on the dimension being measured (liabilities, funding gaps or sustainability). See Blanchet and Ouvrard (2007) and Boado-Penas et al. (2010) for a discussion.

\section{PAYG Point scheme}

24. In a point scheme, the accumulated rights of an individual are calculated in terms of number of points accumulated over the working life. The number of points acquired by an individual each year is determined by dividing contributions paid by the purchasing value of the point. The pension at retirement is calculated by multiplying the number of points by the service (or selling) value of the point. The service 
value of the point is identical for all insured individuals. It converts the points into monetary values at the liquidation but also during retirement. Thus, pension levels during retirement are revalued with respect to its evolution (Box 2).

25. The purchasing value of the point and the service value of the point are the two key parameters for the steering of the scheme. They are normally adjusted to ensure that the scheme remains in balance. In the short run, the scheme can be in deficit if the contributions paid are below the current pension spending (not in the simulation exercise below). In the long run, point prices are set to balance the scheme over the projection period. The setting of point prices depends on the projection of life expectancy by age cohort.

\section{Box 2. Modelling a point scheme}

At the individual level, the number of points (NP) acquired each year is obtained by dividing the contributions by the purchasing value of the points (AV):

$$
N P_{i t}=\frac{\tau * W_{i t}}{A V_{t}}
$$

The sum of points accumulated during the career at the retirement year $\mathrm{T}$ is:

$$
K P_{i T}=\sum_{t=1}^{T} N P_{i t}
$$

The pension at retirement year $\mathrm{T}$ of an individual (i) is calculated by multiplying the capital of points by the service (or selling) value of the point, denoted $\mathrm{VS}_{\mathrm{t}}$ :

$$
P_{i T}=K P_{i T} * V S_{t}
$$

The service value of the point is identical (in general) for all insured individuals. It converts the points into monetary values at the liquidation and also during retirement. Thus, pension levels during retirement are revalued with respect to its evolution. The service value of the point is one of the steering parameters of the scheme; it can be adjusted every year to ensure the balance of the pension scheme. It thus ensures equality between resources and pension outlays.

The short-term balance of the pension scheme is given by the PAYG spending and income flows. With NRt the number of retirees and total contributions $C(t)=\tau * \sum_{i=1}^{N S_{t}} W_{i t}$, the balance is then:

$$
C(t)-\sum_{i=1}^{N R_{t}} P_{i t}=X_{t}
$$

The short run balance depends on the contribution rate, the changes in the payroll and the service value of the point. The contribution rate and the service value of the point can be modified to cope with short-run imbalances.

The service value of the point could be adjusted annually to balance the scheme. In that case, pensions would be very volatile depending on payroll volatility and demographic support ratio variations. The service value of the point can also be adjusted in line with inflation to protect retirees' purchasing power. Finally, the service value of the point can be adjusted to guarantee the actuarial or multiannual balance of the scheme. The service value of the point is the same for all pensioners. It mutualises the risks associated with individual characteristics such as age or survival probabilities.

Denote $\mathrm{N}(\mathrm{a})$ the number of contributors of age a, $\mathrm{C}(\mathrm{a})$ their contributions and e and $\mathrm{d}$ the respective entry age and retirement age of the scheme. At year $t$, the contributions to the scheme are:

$$
C(t)=\sum_{a=e}^{d-1} N_{a}(t) * C_{a}(t)
$$

The counterparts to these contributions are the retirement rights acquired by individuals. They are the liabilities $\mathrm{L}(\mathrm{t})$ of the scheme. The value of the liabilities is given by multiplying the acquired rights at each age by the purchasing price of a differed life annuity which gives the actual value of one unit of pension served during retirement. The life annuity is differed because it is bought before the retirement year. ${ }^{1}$

Denote $L_{(a, d-a)}$ the differed life annuity from age $d$ of retirement when the contributor is of age $a(a<d$ and $d-a$ is the differed period) at year $\mathrm{t}^{2}$ These life annuities are determined based on the mortality table of the scheme's population (with $L_{a}$ the survival probability at age a of the scheme population) and a discount rate $\beta$ : 


$$
\text { for } a<d \quad L A_{a, d-a}=\sum_{j=0}^{\infty} \frac{L_{d+j}}{L_{a}(1+\beta)^{d-a+j}}
$$

Then, the liabilities generated by the contributions $\mathrm{C}(\mathrm{t})$ are given by:

$$
\mathrm{L}(\mathrm{t})=\sum_{a=e}^{d-1} N_{a}(t) * C_{a}(t) * \frac{V S_{t}}{V A_{t}} * L A_{a, d-a}
$$

The scheme is actuarially balanced when the contributions are equal to the liabilities they generate, that is:

$$
L(t)=C(t)
$$

The service value of the point or the rate of returns on contributions $\left(R_{t}=\frac{V S_{t}}{V A_{t}}\right)$ corresponding to the actuarial balance of the scheme is calculated by considering the representative contributor of the average age (â) of the scheme's population. The liabilities related to that contributor are:

$$
\mathrm{L}(\mathrm{t})=\sum_{a=e}^{d-1} N_{a}(t) * C_{a}(t) * \frac{V S_{t}}{V A_{t}} * L A_{\hat{a}, d-\hat{\mathrm{a}}}
$$

where LA(â, d-â) is the differed life annuity related to the whole population of contributors to the scheme represented by this average contributor of age â and with a differed period d-â.

Combining equations (7) and (9) gives the life annuity for this average contributor of age â:

$$
L A_{\hat{\mathrm{a}}, d-\hat{\mathrm{a}}}=\frac{\sum_{a=e}^{d-1} N_{a}(t) * C_{a}(t) * L A_{a, d-a}}{\sum_{a=e}^{d-1} N_{a}(t) * C_{a}(t)}
$$

With the balancing condition of the scheme (equation 8), one can solve equation 10) to obtain the average age of the representative contributor â the so-called "theoretical actuarial age" of the scheme and also the theoretical equilibrium return of the scheme, $R(t)$, which is:

$$
\hat{R}(t)=\frac{1}{L A_{\hat{a}, d-\hat{a}}(t)}
$$

The theoretical rate of return decreases with the rise in the theoretical actuarial age â, because the contributors are getting older and the differed period (distance to retirement) is reduced; this increases the price of one unit of the life annuity and decreases therefore the rate of return. The theoretical return decreases also with the duration in retirement. Indeed, a rise of life expectancy at retirement age induces an increase of the price of one unit of life annuity.

1. See Vernieres (2004a; 2004b) for a presentation of DC point schemes and comparisons of the pricing of pension schemes.

2. See Mackenzie (2006), for modelling life annuities and also a discussion of annuity markets and pension reform.

\section{The baseline}

\section{Demography}

26. The baseline scenario starts in year 0 with an equal size of cohorts of working age. In each scheme there are 100 men and 100 women of age 20 to 59 that contribute to the scheme each year. The scheme is balanced in year 0 and the cohorts entering in retirement have a 40 year complete career.

27. The schemes are funded under the PAYG principle: the contributions received during a year are used to pay current pension benefits. 
28. The baseline demographic scenario uses a constant mortality rate. First, mortality rates by age and year from 1950 to 2050 for France are used to calculate survival rates by age, year and life expectancy. ${ }^{2}$ Then, the average mortality rate by age (of the 60-90 year olds) of the 1980s is applied each year to all cohorts to determine the population of retirees. Thus there is no ageing and the number of retirees is constant. The baseline scenario retirement age is 60 .

29. The demographic shock scenario corresponds to a longevity shock. From year 0 to 10 a moving average mortality rate by age (of the 60-90 year olds) is applied each year to all cohorts to determine the population of retirees to phase in the ageing shock. From year 10, the corresponding French mortality rates per age and year are applied. As the mortality rate diminishes, the population of retirees increases causing a decrease of the support ratio (the number of contributors per pensioner) (Figure 6). From year 70 the ageing process vanishes and the mortality rates are constant.

Figure 6. Evolution of the support ratio in the two scenarios

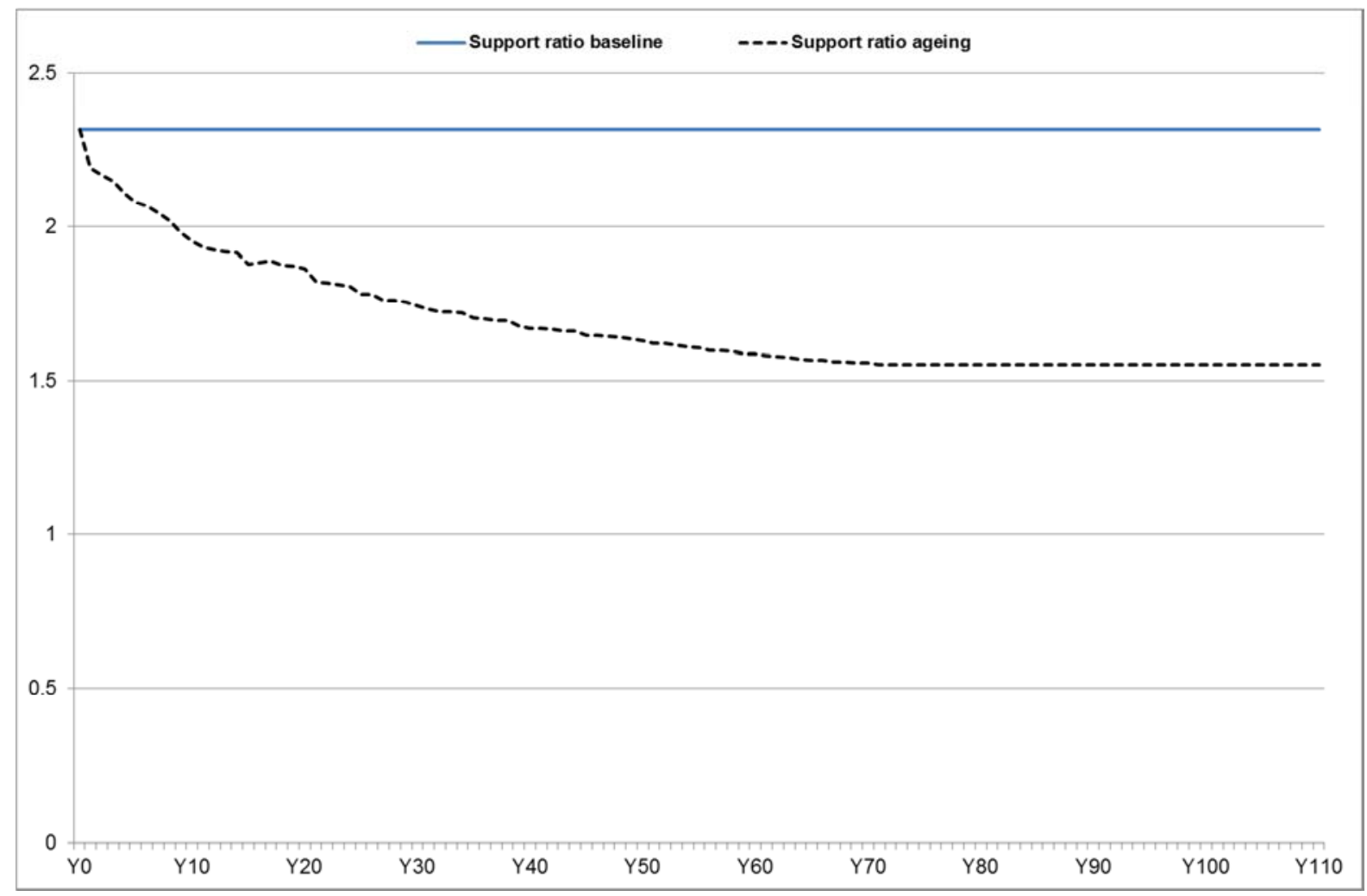

Note: The support ratio decreases as the number of retirees increases up to year 70 ; then, as the mortality rate is constant the support ratio is constant.

Source: OECD simulations.

\section{Wage distribution and parameters of the schemes}

30. The initial wage distribution matches the French 2004 wage distribution. The average and standard-deviation of each decile of the 2004 wage distribution are used to draw randomly a wage for each individual following the uniform law. Individuals are distributed among the different deciles to match the real distribution of wages. At ages 27 and 41, following an estimated transition matrix from one decile to

2. The French mortality tables are used because they were available by age and year from 1950 . 
another one by age, individuals are moved randomly from one decile to another one. This property of the wage distribution could be used in future work to analyse equity and fairness issues.

31. The initial wage follows the growth rate of the average wage per worker (1980-2004) of France in the first 24 periods, and then wages are projected to increase by $3.2 \%$ per year.

32. Unemployment is introduced in the income distribution. Each year, 5\% of workers are unemployed and have zero salary. Half of the unemployed are distributed randomly among young cohorts (under 28) and the other half among older workers (42 and plus). It is assumed that during unemployment spells no contribution payments are made and no pension rights are acquired. ${ }^{3}$ Unemployment introduces heterogeneity in the number of periods contributed and pension levels in addition to the heterogeneity coming from the wage distribution. Differences in the wage levels between men and women are also introduced. Women have on average a lower wage than men. These dimensions (unemployment and differences between men and women) could also be used for the analyses of equity issues and risk sharing properties of the two schemes.

33. The contribution rate is set initially at $14 \%$ in year 0 and $18 \%$ in the long run. The pension rate in the DB scheme is $50 \%$ of the career average wage based on the number of years of contribution (maximum 40 years).

34. In the DC point scheme, the same contribution rate as in the DB scheme is applied to determine the amount of contributions. The contributions paid are then converted into points given the purchasing value of the point which depends on the price of a differed life annuity for the average contributor (Box 2). In the point scheme, the service value of the point is adjusted to balance the scheme each year.

35. In the following simulation exercises, the timing of all shocks is from year 0 . The baseline scenario is the scenario without ageing. All simulation results are given in comparison with the baseline scenario. The two schemes are balanced under the baseline scenario.

\section{Vulnerability of pension schemes to shocks}

\section{The impact of a productivity shock}

36. The stylised model was used to simulate the impact of a productivity shock on the DB scheme and the point DC scheme. Under the assumption that productivity and real wages move in tandem over longer periods, the productivity shock is simulated as a permanent reduction in the growth rate of the real wage by 1 percentage point.

37. Due to the shock, the balance of the DB scheme moves gradually into deficit. As initial pensions are tied to wage developments, the average pension decreases considerably in the long run in comparison with the baseline average pension. Revenues go down by even more, as revenues depend on the wage bill, which is much larger than the pension bill. Pension spending decreases progressively from year 0 with the increase of cohorts of retirees affected by lower productivity trend growth (Figure 7). Indeed, from year 0 to year 30, cohorts of retirees unaffected by the productivity shock are replaced by cohorts of new retirees with part of their career affected by the productivity shock. During this time span the pension bill decreases less than the revenues of the scheme. From year 40 when the first cohort of retirees with a complete career under the lower productivity trend is in retirement, the decline in pension spending accelerates as all

3. The assumption that during unemployment spells individuals do not contribute and acquire no pension rights is for simulation reasons. In most of countries, at least up to some duration, unemployment spells are contributing periods that give pension rights. 
following cohorts in retirement have lower pensions as compared to the baseline scenario. In the long run (after year 70), when all cohorts in retirement have a complete career, pension revenues and spending move in parallel.

Figure 7. The effect of a productivity growth slowdown on a DB scheme

Difference with respect to the baseline scenario

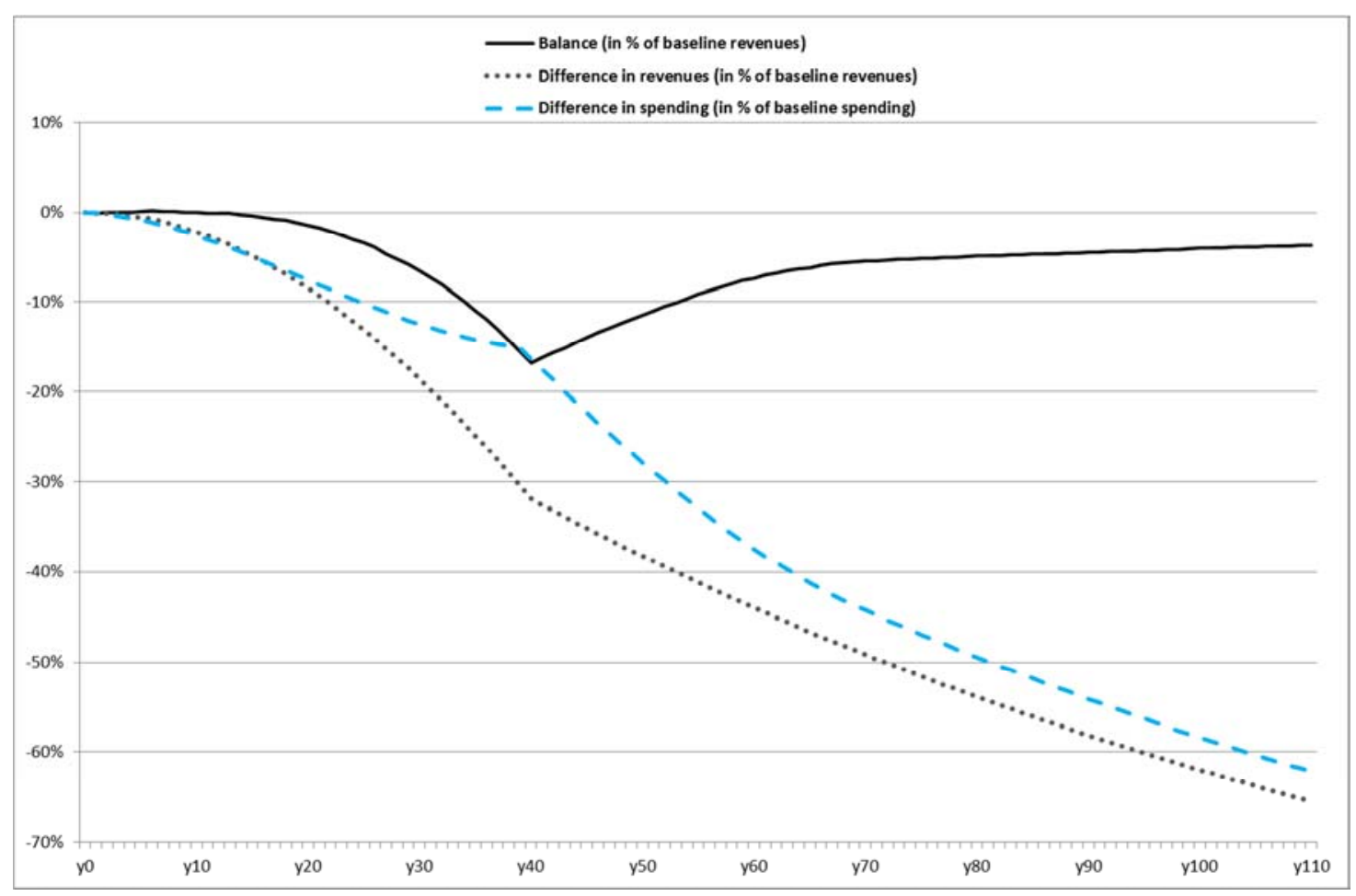

Note: There is no ageing in the baseline scenario. The impact of the productivity shock is measured by the balance of the scheme under the productivity shock scenario expressed as a per cent of revenues of the baseline scenario. The difference in pension spending is expressed in per cent of spending in the baseline. The difference in revenues is expressed in per cent of revenues in the baseline scenario.

Source: OECD simulations.

38. The DC point scheme is balanced by definition. It is the service value of the point which decreases to balance the scheme. From year 0 to year 40, the service value of the point decreases with contributions as the liabilities of the scheme are only progressively affected by the shock. Indeed, the cohorts in retirement have accumulated their pension rights under past wage developments and purchasing value of the points. As new cohorts entering retirement are affected by the shock and have lower pension rights, the service value of the point converges to a new-long run balancing level, which is $20 \%$ below the baseline level.

39. The average pension of the DC point scheme is much affected as it decreases in line with the contributions received by the scheme. The decrease of the average pension (in Figure 8) is close to the decrease in revenues in Figure 7. 
Figure 8. The effect of the productivity shock on a point DC scheme

Difference with respect to the baseline scenario

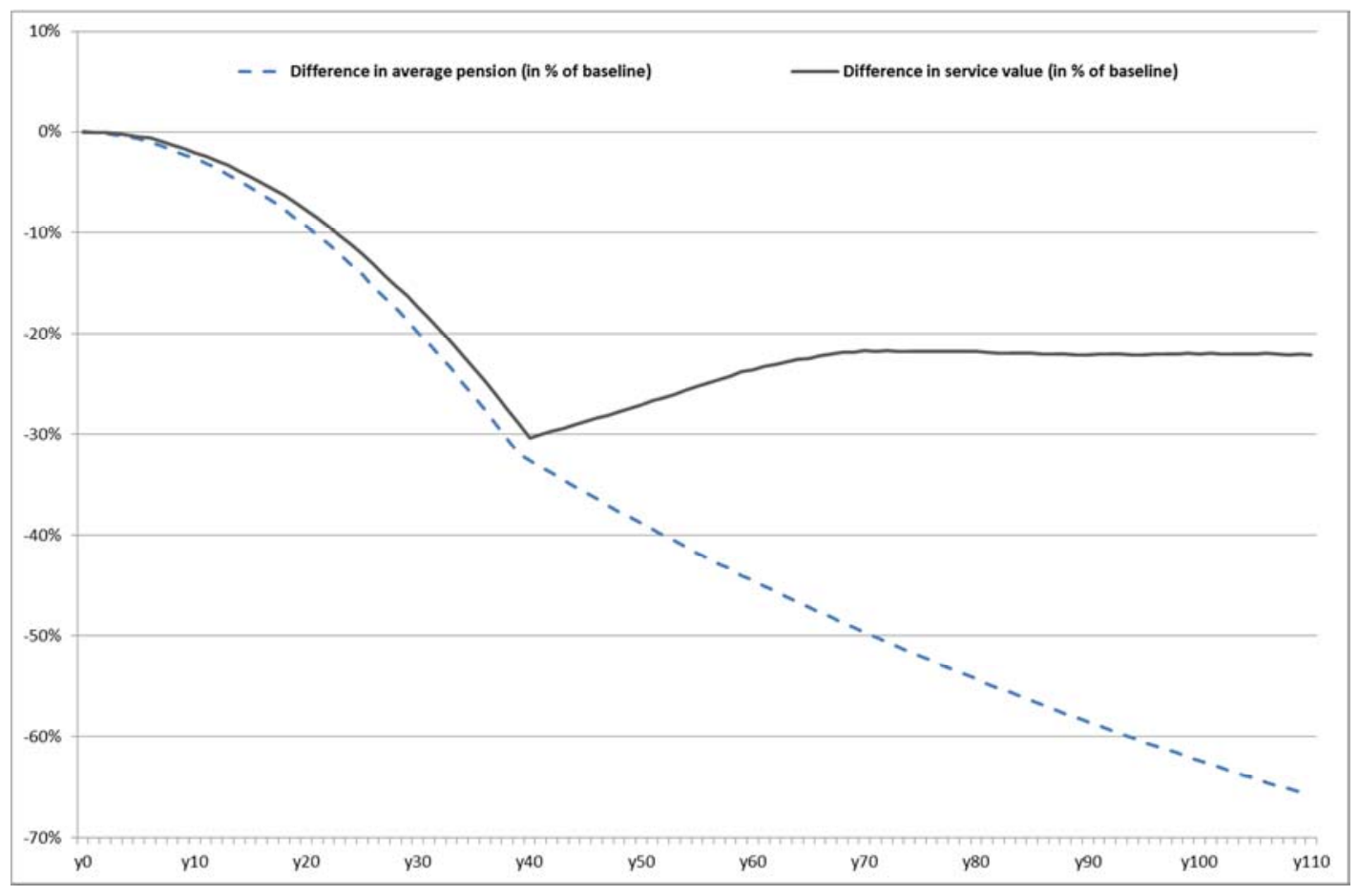

Note: There is no ageing in the baseline scenario. The difference in average pension is expressed in percentage of the baseline average pension. The average pension is calculated over all cohorts in retirement each year. The difference in service value is expressed in percentage of the baseline service value.

Source: OECD simulations.

\section{The impact of a negative migration shock}

40. The migration shock is a permanent negative shock. From the initial year of the shock, the size of the cohort entering the labour market (aged 20) is lowered permanently by 5\%. 40 years later all working cohorts are 5\% smaller than in the baseline. The support ratio (contributors per pensioner) decreases continuously from the initial year of the shock to 40 years later as the cohorts of lower size age. 40 years after the shock, these smaller cohorts start retiring which improves the support ratio progressively. Seventy years after the shock, all retired cohorts are $5 \%$ smaller than in the baseline.

41. The impact of the negative migration shock on the balance of the DB scheme follows the evolution of the support ratio and is temporary. From the initial year of the shock to 40 years later the balance of the scheme deteriorates. Then, as these cohorts of lower size retire, the support ratio improves and so does the balance of the scheme. In the long run, the DB scheme reverts to balance (Figure 9).

42. The DC scheme is balanced by definition. The negative impact of the migration shock is absorbed by declining pensions. As revenues of the scheme decline, the service value of the point is reduced to balance the scheme. The average pension initially decreases in line with contributions and then recovers very gradually. 
Figure 9. The impact of a negative migration shock on the DB and DC scheme

Difference with respect to the baseline scenario

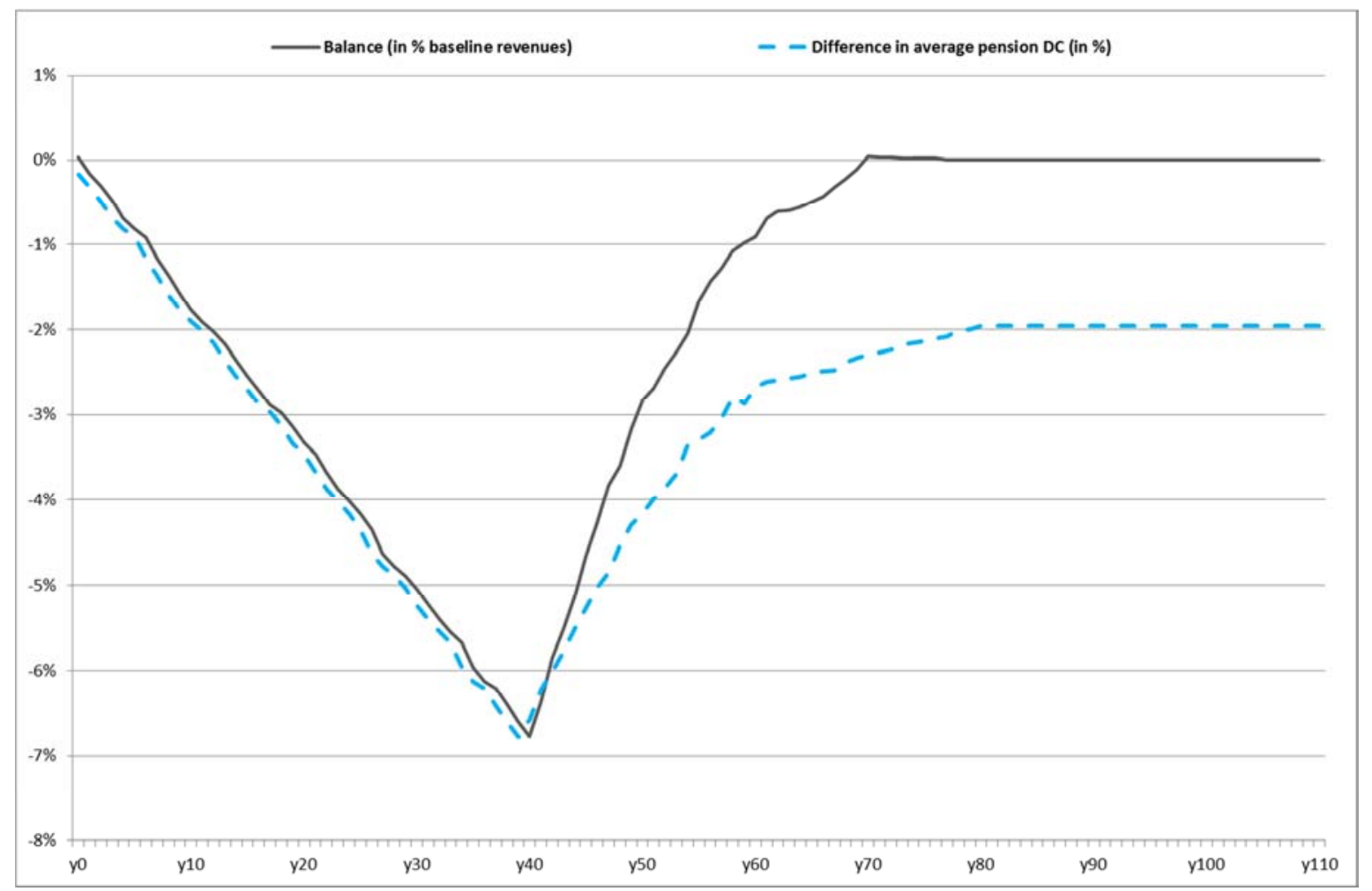

Note: In the DB scheme the impact of the migration shock is measured by the balance of the scheme under the migration scenario expressed as a per cent of revenues of the baseline scenario. As the DC scheme is balanced each period thanks to the variation of the service value of the point, the impact of the migration shock is expressed as the percentage difference of the average pension compared with the baseline.

Source: OECD simulations.

\section{The impact of ageing}

43. The demographic shock scenario corresponds to a longevity shock. It corresponds to an increase of life expectancy, which implies a decrease of the mortality rate at old ages. The number of elderly individuals increases. The longevity shock induces a fall of the support ratio from 2.3 to 1.5 in the long run (Figure 6 above).

44. In the DB scheme, ageing induces a progressive deterioration of the balance of the scheme (Figure 10). The average replacement rate (the ratio of the average pension to the average wage) in the ageing scenario is lower than in the baseline due to a decline in the average pension, reflecting the fact that pensions are averaged among all cohorts in retirement, with the oldest pensioner cohorts having lower pensions than younger cohorts as pensions are indexed to prices, rather than wages.

45. The variables showing the impact of the ageing (Figure 10 and the following) are not straight lines because the mortality rates in the ageing scenario do not change in a smooth way and the small fluctuations of the contribution rate that balances the baseline scenario have a larger impact on the scheme's revenues. The curves are smoothed. 
Figure 10. The impact of the longevity shock on the DB scheme

Difference with respect to the baseline scenario

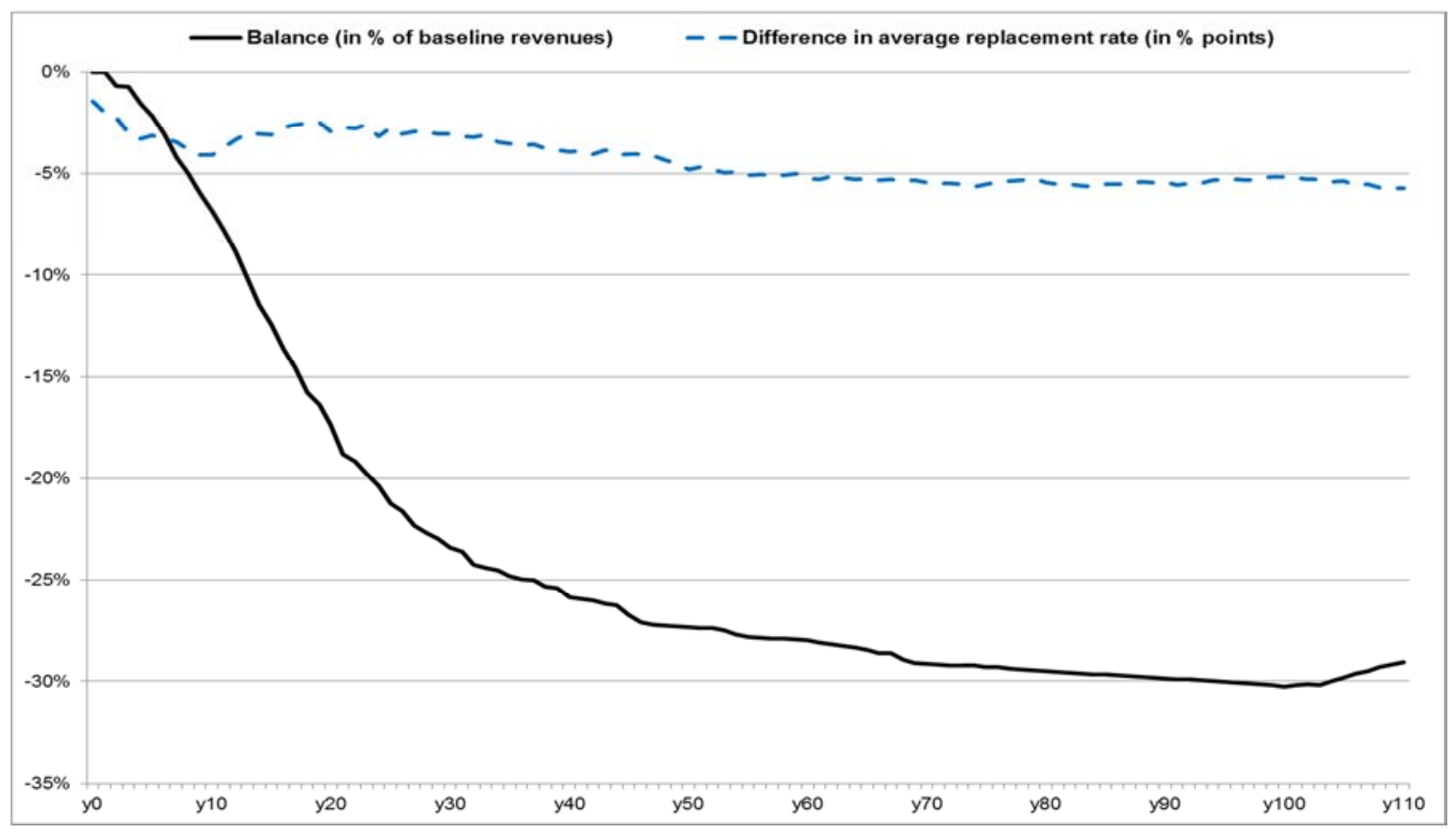

Note: The ageing shock mimics the French life expectancy developments. The impact of ageing is measured by the balance of the scheme under the ageing scenario and is expressed as a per cent of revenues of the baseline scenario. The average replacement rate is the ratio of the average pension to the average wage.

Source: OECD simulations.

46. In the DC point scheme, the negative effect of the same ageing process is reflected in a decline in the replacement rate (Figure 11). The decline in the replacement rate is larger than for the DB scheme. Also, the service value of the point diminishes in line with the support ratio whereas the purchasing value of the point - defined as the price of one unit of differed life annuity - increases with life expectancy. Therefore, individuals gain a lower number of points at a lower service value. The adjustment of the point values keeps the scheme in balance. 
Figure 11. The impact of the longevity shock on a DC scheme

Difference with respect to the baseline scenario

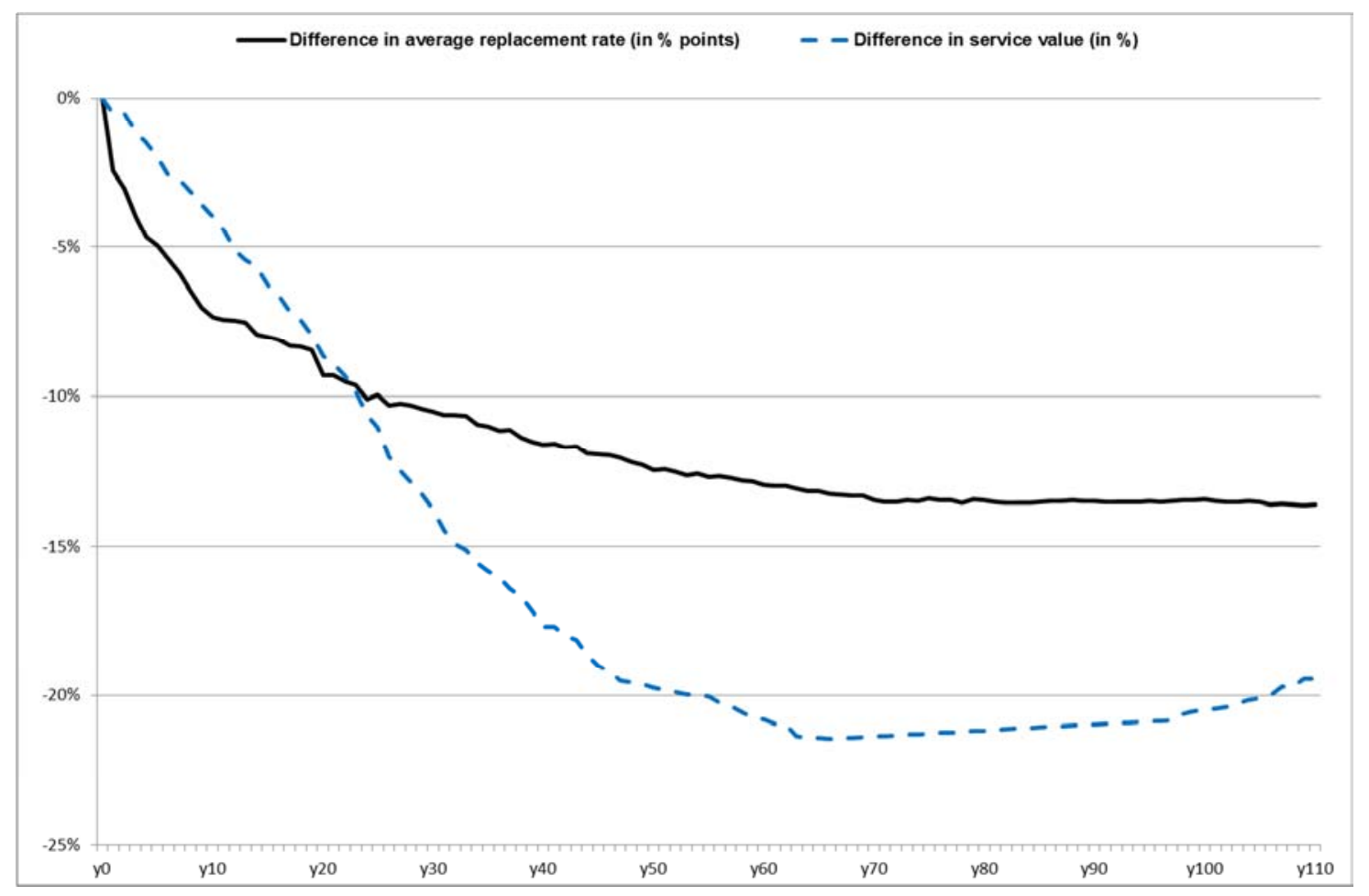

Note: The impact of ageing is measured by the change in the service value of the point and hence the average replacement rate. Recall that the DC point scheme is balanced each year.

Source: OECD simulations.

\section{Reforming pension schemes}

47. To maintain the sustainability of pension systems in the face of an ageing population, governments have the following policy options: they can increase the contribution rate, decrease the pension rate (i.e. the accrual or liquidation rate) or increase the retirement age. In the DB scheme, changing the up-rating of past wages is also a policy option. The effect of these reforms are analysed below and the results should be compared with the longevity shock scenario.

\section{The impact of increasing the contribution rate in the two schemes}

48. In the DB scheme, the contribution rate needs to be increased by 5 percentage points as compared to the baseline to cope with the ageing shock (Figure 12). In the long run, the balance of the DB scheme reverts to the baseline level. Pension levels are not affected by the reform.

49. In the point DC scheme, the contribution rate is increased by almost the same amount as in the DB scheme. Increasing the contribution rate limits the reduction in the average replacement rate due to the ageing shock to 6 percentage points (against a 13 percentage point reduction in the ageing scenario). However, as the contribution rate is increased, the service value of the point decreases to keep the point scheme in balance.

50. Increasing the contribution rate alone is not the best way of adjusting the balance of the point scheme. In principle, it is the purchasing value and/or the service value of the point that is adjusted to 
ensure the actuarial balance of the scheme. However, in some countries, the short-run funding needs are financed by increasing the contribution rate, but the additional contributions do not generate additional pension rights.

51. Also, increases in contributions may be achieved either by increasing the contribution rate or enlarging the contribution base. For example, extending the working life or reducing unemployment of older workers helps because they increase the contribution base.

\section{Figure 12. The impact of increasing the contribution rate on the DB and DC schemes}

The simulation results should be compared with the longevity shock scenario (Figures 10 and 11)

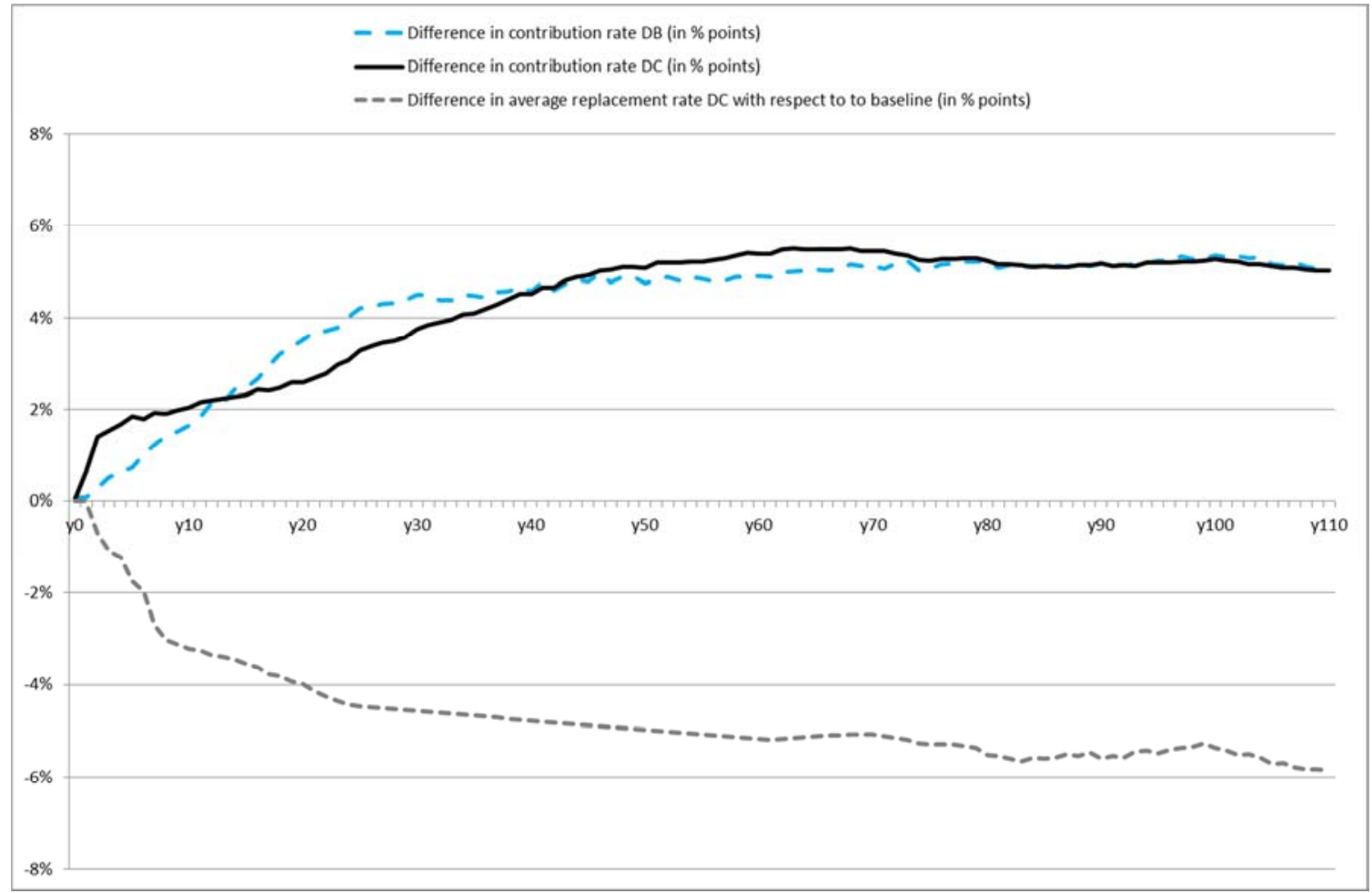

Note: From year 0 the contribution rate is increased progressively to fund the financing gap induced by ageing. The contribution rate is the same for the longevity shock and baseline scenario. In the point DC scheme, as the scheme is balanced, the objective of the reform is to counterbalance the effect of ageing on pension levels.

Source: OECD simulations.

\section{The impact of increasing the retirement age in the two schemes}

52. A higher retirement age lowers pension payments as the number of cohorts in retirement diminishes. The retirement age increase is put in place swiftly from age 60 to age 65 in the first year of the reform.

53. In the first years after the reform, the surplus of the balance of the DB scheme is important because the number of cohorts contributing increases from 40 to 45 while the number of cohorts of retirees decreases from 30 to 25 . The transition of the balance of the scheme to its long run level is protracted as it takes 30 years for all retirees not affected by the reform to leave the scheme. When all cohorts in retirement have 45 years of contributions and therefore a higher level of pension, the surplus of the scheme declines to its long-run level. 
54. In the DB scheme, in the long run, the balance due to ageing swings from a deficit of close to $30 \%$ (Figure 10) to a surplus of 7\% of baseline revenues, following the increase in the retirement age (Figure 13). Still, when increasing the retirement age, the average replacement rate is lower than in the baseline scenario as with the longevity shock scenario. However, when increasing the retirement age, the increase of the average wage explains the lower average replacement rate, while in the longevity shock scenario, it is the increase in life expectancy with pension indexation which explains the lower average replacement rate compared with the baseline. But the pension level is still 2 percentage points higher in the increasing retirement age scenario compared with the baseline.

55. Increasing the retirement age restores the financial balance of the scheme while preserving the adequacy of pensions. The impact of the reform operates through the rise in the support ratio which rises from 1.5 under the ageing scenario to 2.1 in the increasing retirement age scenario.

56. However, the final outcome for individual pension benefits depends on labour market developments. Increasing the official retirement age is not enough. Options for early retirement also need to be removed. Well-functioning labour markets and targeted policies to increase the employment of older workers are key factors to raise the employment of older workers. Otherwise, lower pension spending would be offset by higher spending on other social programmes.

Figure 13. The impact of increasing the retirement age from 60 to 65 on the DB scheme

The simulation results should be compared with the longevity shock scenario (Figure 10)

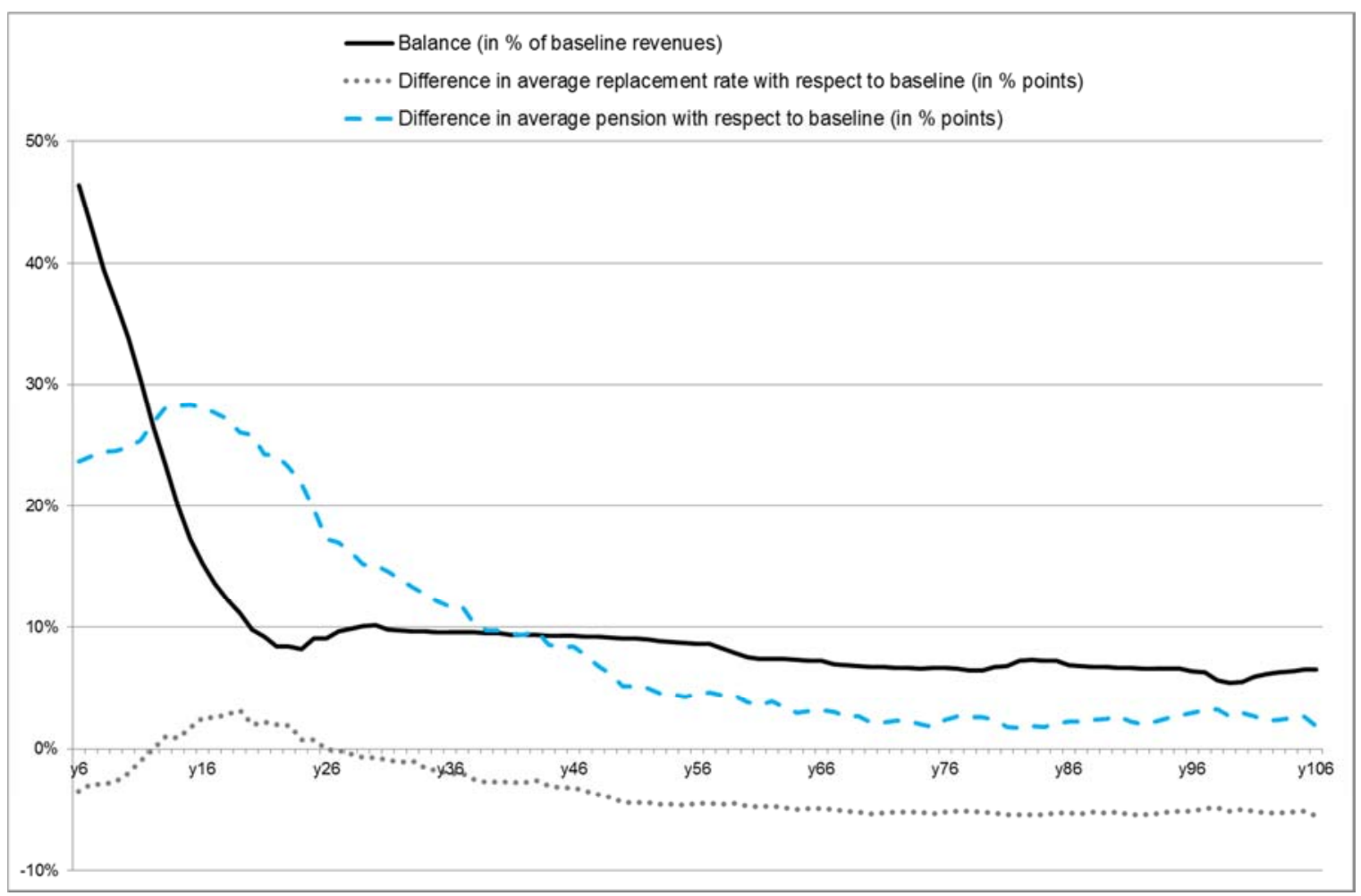

Note: The retirement age is increased in year 0 from 60 to 65 with no phasing in. This implies that during five years there are no new retirees. At year 6 , there are new retirees with 45 years of contributions. It takes 30 years for all cohorts of retirees not concerned by the reform to leave the scheme.

Source: OECD simulation. 
57. In the point scheme, in the short run, as it is a balanced PAYG scheme all contributions serve current retirees. Raising the retirement age induces a sharp increase in contributions, while the number of retirees diminishes. Therefore, in the first years after the reform the retirees not affected by the reform (in terms of increased years of contributions) benefit from the reform. Their pension level increases up to $80 \%$, which is comparable to the shape of the surplus of the DB scheme after the reform.

58. In the point scheme, increasing the retirement age induces an increase in pension benefits as compared with the baseline by 9 percentage points over the long run. Individuals contribute during five more years and therefore accumulate more pension rights while the revenues of the scheme increase as there are more working cohorts contributing. Also, the average replacement rate is only 3 percentage points below that of the baseline against 13 percentage points in the longevity scenario (Figure 11). The service value of the point goes down considerably to balance the point DC scheme (Figure 14).

Figure 14. The impact of increasing the retirement age from 60 to 65 on the point scheme

The simulation results should be compared with the longevity shock scenario (Figure 11)

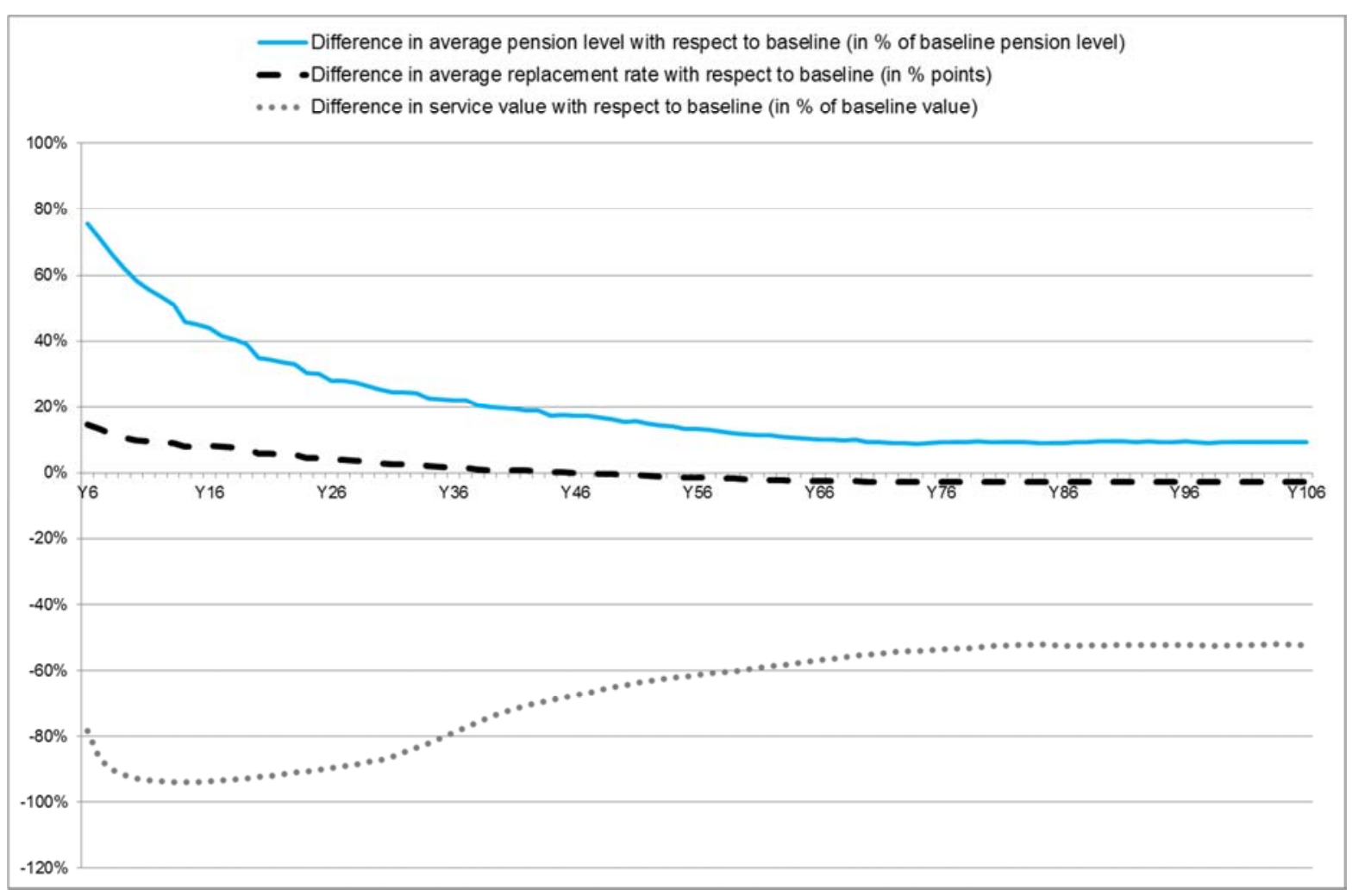

Note: The retirement age is increased in year 0 from 60 to 65 with no phasing in. This implies that during five years there are no new cohorts of retirees. At year 6 , there are new retirees with 45 years of contributions. It takes 30 years for all cohorts of retirees not affected by the reform to leave the scheme.

Source: OECD simulation.

\section{Additional policy options in the DB scheme}

\section{The impact of decreasing the pension rate}

59. In the DB scheme, the pension rate is applied to the reference wage to determine the pension level. The pension rate (also called the liquidation rate) is the sum of the annual accrual rate. The pension 
rate can be increased or decreased with respect to deferred or early retirement. Though this is a politically sensitive instrument, it can be used to reform pension schemes. Lowering the pension rate has a direct effect on pension spending and the adequacy of pension levels.

60. The pension rate is reduced by more than 10 percentage points from $50 \%$ to $38 \%$ to fully counteract the ageing shock (Figure 15). The impact on the replacement rate is large as the average replacement rate declines by 13 percentage points in the long run as compared to a decline of 5 percentage points in the longevity scenario (Figure 10).

Figure 15. Adjusting the pension rate on a DB scheme

The simulation results should be compared with the longevity shock scenario (Figure 10)

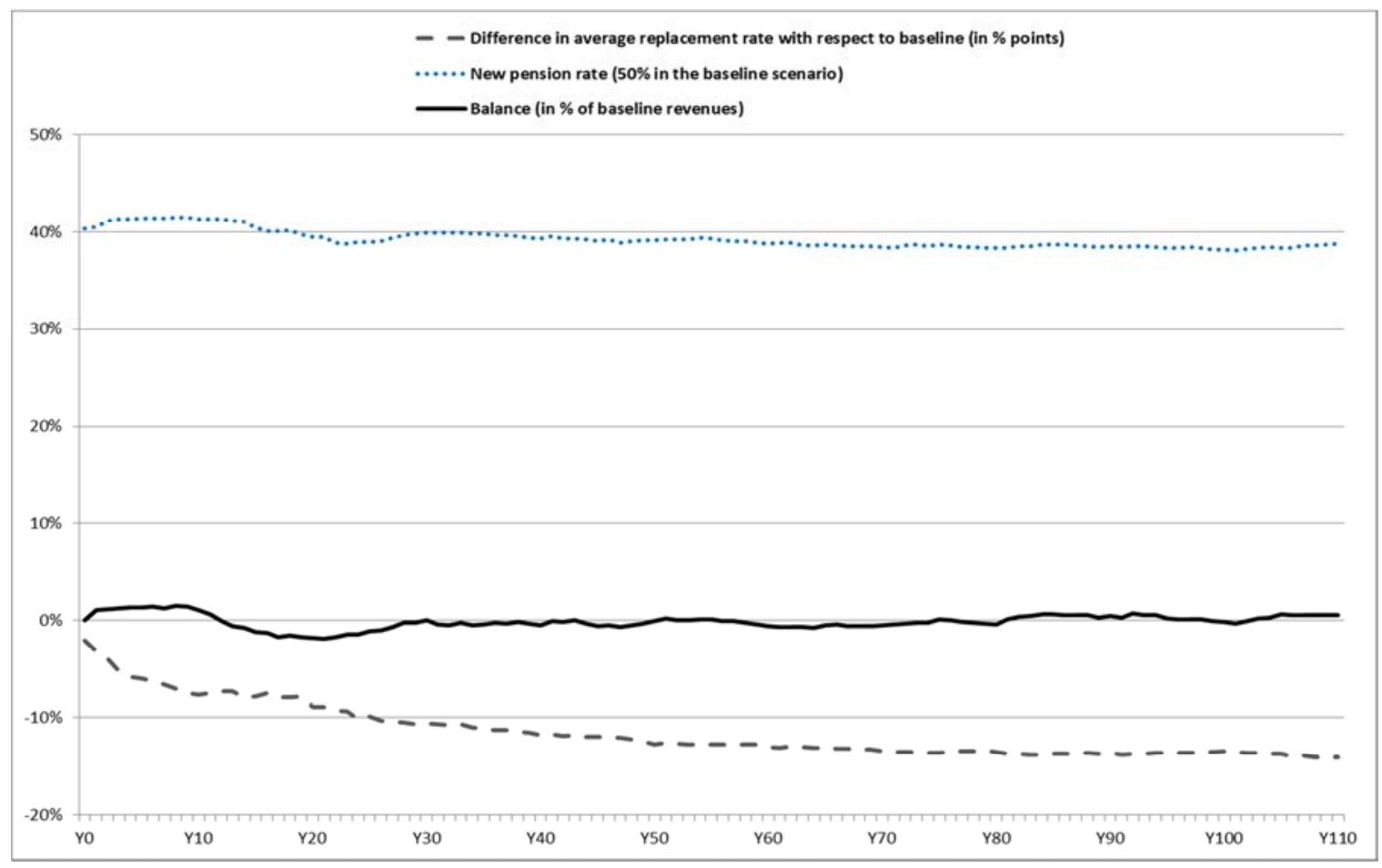

Note: The reform consists of decreasing the pension rate to close the financing gap due to the ageing shock. The pension rate in this scenario is reduced sharply compared with the baseline scenario, where the pension rate is $50 \%$.

Source: OECD simulations.

\section{The impact of changing the up-rating rate on the DB scheme}

61. In the DB scheme, the pension at retirement is calculated based on the average career wage. The calculation of the career average wage is done by up-rating past wages to the retirement year with the growth rate of the economy-wide average wage. The reform consists of up-rating with inflation instead of the average wage growth rate. As the inflation rate is lower than the average wage growth rate, the reform induces a decrease of the individual average career wage. In the long run, the reference wage is $27 \%$ lower when wages are up-rated with inflation compared with an up-rating by the economy-wide average wage.

62. In the short run, the change of the up-rating from the growth rate of the economy-wide average wage to inflation reduces the balance of the scheme progressively because only new cohorts of retirees are affected. Also, the impact of the reform (Figure 16) is non-linear because in the short run pension spending 
is affected by the ageing process and past dynamics of wages. In the long run, the effect of the reform is smoother as ageing the ageing process peters out.

63. As pension levels at retirement are lower, the balance of the scheme improves going from a deficit of nearly $30 \%$ of baseline revenues in the ageing scenario (Figure 10) to a surplus of $5 \%$ of baseline revenues in the reform scenario (Figure 16). The average replacement rate decreases in the up-rating reform compared with the ageing scenario.

\section{Figure 16. The impact of an up-rating reform}

The simulation results should be compared with the longevity shock scenario (Figure 10)

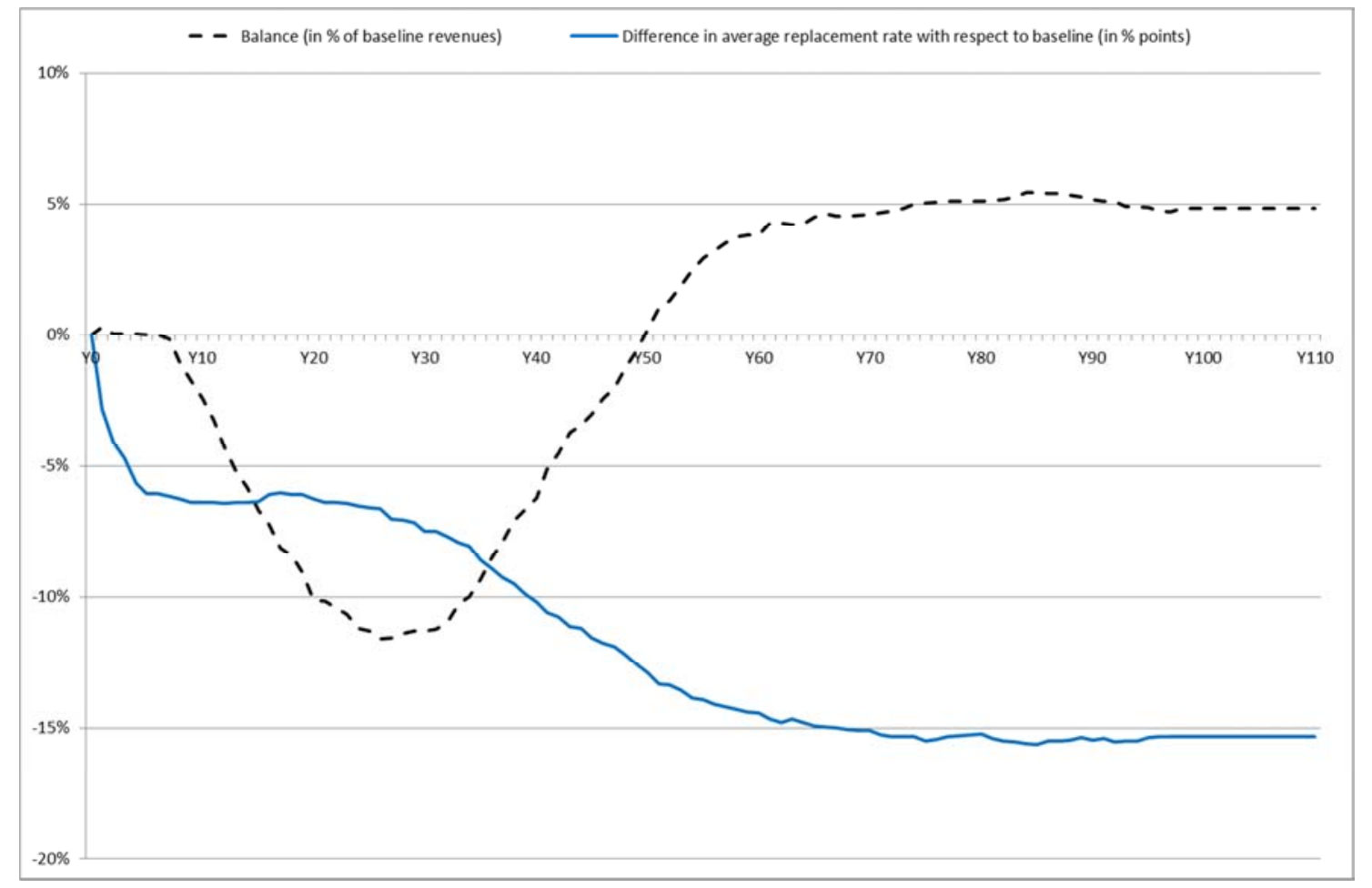

Note: The reform consists of up-rating past wages to calculate the average career wage at retirement with inflation instead of average wage growth rate.

Source: OECD simulations. 
ECO/WKP(2014)30

\section{BIBLIOGRAPHY}

Blanchet, D. and J.-F. Ouvrard (2007), «Indicateurs d'engagements implicites des systèmes de retraite : que mesurent-ils exactement? », Revue Française d'Économie, Vol. 22-1, pp 3-47.

Boado-Penas, M.d.C., C. Vidal-Melia and J. Sakamoto (2010), "Models of the Actuarial Balance of the Pay-As-You-Go Pension System. A Review and some Policy Recommendations", Working Paper, Keele University.

Holzmann, R. and E. Palmer (2006) "Pension Reform: Issues and Prospects for Non-Financial Defined Contribution (NDC) Schemes". Washington DC: World Bank ed.

Mackenzie, G. A. (2006), Annuity Markets and Pension Reform, Cambridge University Press, Cambridge.

OECD (2013), Pensions at a Glance 2013: OECD and G20 Indicators, OECD Publishing, Paris. doi: 10.1787/pension_glance-2013-en.

Samuelson, P.A. (1958), “An Exact Consumption-Loan Model of Interest with or without the Social Contrivance of Money”, Journal of Political Economy, Vol. 66, pp. 467-82.

Settergren, O. and B. D. Mikula (2006), "The Rate of Return of Pay-As-You-Go Pension Systems: A More Exact Consumption-Loan Model of Interest," in: Holzmann, R. and E. Palmer (eds), Pension Reform: Issues and Prospects for Non-Financial Defined Contribution (NDC) Schemes, World Bank, pp 117-143, Washington DC.

Valdès-Prieto, S. (2000), “The Financial Stability of Notional Account Pensions”, The Scandinavian Journal of Economics, Vol. 102, pp. 395-417.

Vernieres, L. (2004a), "Barèmes de décote et surcote, rachat de périodes d'études et neutralité actuarielle dans la tarification des régimes de retraite : méthodologie et comparaisons internationales", Questions Retraites, n. 2004-66.

Vernieres, L. (2004b), "Méthodologie de comparaison des régimes de retraite par répartition. La tarification et l'équilibre actuariel des régimes", Questions Retraites, n. 2004-64. 
$\mathrm{ECO} / \mathrm{WKP}(2014) 30$

\section{WORKING PAPERS}

The full series of Economics Department Working Papers can be consulted at www.oecd.org/eco/workingpapers

1133. Overcoming vulnerabilities of pension systems

(July 2014) by Falilou Fall and Debbie Bloch

1132. Overcoming vulnerabilities of health care systems

(July 2014) by Mauro Pisu

1131. Overcoming vulnerability of unemployment insurance schemes

(July 2014) by Jon Pareliussen

1130. Vulnerability of social institutions: Lessons from the recent crisis and historical episodes (July 2014) by Falilou Fall, Mauro Pisu, Jon Pareliussen and Debbie Bloch

1129. An update of the OECD international trade equations

(June 2014) by Myriam Morin and Cyrille Schwellnus

1128. What explains the volume and composition of trade? Industrial evidence from a panel of countries

(June 2014) by Asa Johansson, Przemyslaw Kowalski, Eduardo Olaberria and Dario Pellegrino

1127. Do resources flow to patenting firms: cross-country evidence from firm level data

(June 2014) by Dan Andrews, Chiara Criscuolo and Carlo Menon

1126. Macroprudential policy tools in Norway: Strengthening financial system resilience

(June 2014) by Yosuke Jin, Patrick Lenain and Paul O’Brien

1125. Strengthening competition in Poland

(June 2014) by Balász Égert and Antoine Goujard

1124. Making the labour market work better in Poland

(June 2014) by Hervé Boulhol

1123. Enhancing competition and the business environment in Hungary

(June 2014) by Alvaro Pina

1122. Tackling labour mismatches and promoting mobility in Hungary

(June 2014) by Stéphane Sorbe

1121. Local public finances and municipal reform in Finland

(June 2014) by Christophe André and Clara Garcia

1120. The economic consequences of ageing: the case of Finland

(June 2014) by Christine de la Maisonneuve, Christophe André, Clara Garcia and Vincent Koen

1119. Making the most of skills in Denmark

(June 2014) by Stéphanie Jamet and Vincent Koen 
1118. Trade specialisation and policies to foster competition and innovation in Denmark (June 2014) by Müge Adalet McGowan

1117. Policies for making the Chilean labour market more inclusive (June 2014) by Aida Caldera Sanchez

1116. Spillover effects from exiting highly expansionary monetary policies

(May 2014) by Łukasz Rawdanowicz, Romain Bouis, Jérôme Brezillon, Ane Kathrine Christensen and Kei-Ichiro Inaba

1115. Economic policies and microeconomic stability: A literature review and some empirics (April 2014) by Paula Garda and Volker Ziemann

1114. How to improve Israel's health-care system (April 2014) by Philip Hemmings

1113. How to improve taxes and transfers in Israel (April 2014) by Philip Hemmings

1112. New evidence on the determinants of industrial specialisation (April 2014) by Asa Johansson and Eduardo Olaberria

1111. Economic growth from the household perspective: GDP and income distribution developments across OECD countries

(April 2014) by Orsetta Causa, Sonia Araujo, Agnès Cavaciuti, Nicolas Ruiz and Zuzana Smidova

1110. Would a growth slowdown in emerging markets spill over to high-income countries? A quantitative assessment (April 2014) By Patrice Ollivaud, Elena Rusticelli and Cyrille Schwellnus

1109. Short-term indicator models for quarterly GDP growth in the BRIICS: A small-scale bridge model approach (April 2014) by Thomas Chalaux and Cyrille Schwellnus

1108. The prudential regulation of financial institutions: why regulatory responses to the crisis might not prove sufficient (March 2014) by William R. White

1107. OECD forecasts during and after the financial crisis: a post mortem (March 2014) by Nigel Pain, Christine Lewis, Thai-Thanh Dang, Yosuke Jin and Pete Richardson

1106. Fairly sharing the social impact of the crisis in Greece (January 2014) by Vassiliki Koutsogeorgopoulou, Manos Matsaganis, Chrysa Leventi and Jan-David Schneider

1105. Dividing the pie in Brazil: income distribution, social policies and the new middle class (January 2014) by Jens M. Arnold and João Jalles 